

\section{ملمص البمث}

درس الباحث روايات الحديث وتعددها واختلافها، وإمكان الترجيح بينها، وأثر ذلك على استتباط الأحكام من الحديث.

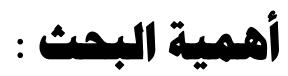

1) أن اختلاف الألفاظ وتعدد الروايات في الحديث سبب رئيس للاختلاف في الاستدلال والاستنباط . r وجوب الموازنة بين الألفاظ والترجيح بينها وأن ذلك ييسر معرفة الصواب ويسهل الترجيح بين الأراء المختلفة . r) ضرورة جمع الألفاظ والروايات والموازنة بينها من خلال النظر في علم العلل

$$
\text { وطنداف الرواة. }
$$

1) بيان الألفاظ الصحيحة للحديث، بناء على دراسة حديثية مقارنة.

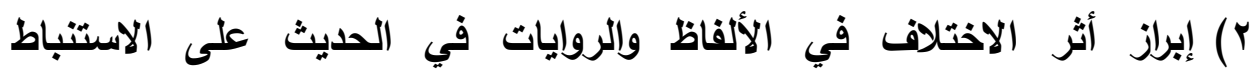
والاستدلال. r) حل أهم الإثكالات المتعلقة بهذا الحديث المهم .

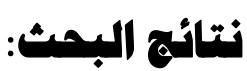

( ) أصح روايات حديث الخثعمية هي رواية ابن عباس عن أخيه الفضل كما نص على ذلك البخاري، وهو صاحب القصة. 
r الأحاديث الصحيحة قد يقع فيها بعض الألفاظ التي لم يتفق عليها، مما يمكن الترجيح بقبولها أو اعتبارها مرجوحة مقارنة بغيرها.

r ب) وجوب الترجيح بين الروايات المختلفة باستعمال طريقة المحدثين في علم العلل ودراسة الأسانيد. كلمات مفتاحية : أثر، اختلاف، استتباط، الألفاظ، الخثعمية. 


\begin{abstract}
The researcher studies prudently narration of Hadith, their multiplicity and differences in order to find out possibility of prepon'dera'tion between them: and the impact on deducing legal rules from Hadeeth as well.
\end{abstract}

\title{
The Importance of the Research:
}

1.The differences of expressions and multiplicity in Hadeeth narration are the main reasons that led to the differences in inferences and deductions.

2. existing obligation of the balance between the expressions and prepon'dera'tion amongst them which may facilitate to identify the truthfulness and pave ways to prepon'dera'tion amongst different new viewpoints.

3.nesccesity of collecting the expressions and narrations of Hadeeth in order to compare them through exploring and probing the rationality science and the layers of narrators.

\section{Objectives of the Research}

This research aims to:

1. explore and probe the correct expressions of Hadith based upon comparative study of selected Hadihs.

2. cast new light on the impact of differences in expressions and Hadith narration on inferences and deductions.

3. solve and tackle problems related to the important selected Hadith.

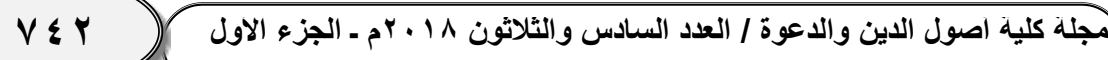




\section{Research Results}

1. the narrations of Alkhatha'amia's Hadith are narration of of Ibn Abas about his brother Alfadel as it has been pointed by Albulkhari who is the owner of the story.

2. The correct Hadiths may contain some expressions which were not accepted by scholars .In such cases, there are some possibilities to be preponderated or to be considered as preponderating Hadiths compared by other Hadiths.

3. existing obligation amongst different narrations by using almhdthin's method in the rationality science and studying ascription of Islamic tradition( Asanid)

Based on the above, the study recommended the following: Students of knowledge and researchers are recommended to pay attention to this great branch of hadith science.

Keywords: Impact, difference, inference, expressions, Alkhatha'amia 
إن الحمد لله نحمده، ونستعينه، ونستففره، ونتوب إليه، ونعوذ بالله من

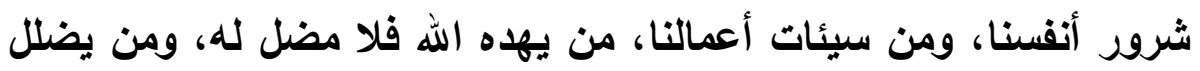
فلا هادي له، وأثثه أن لا إله إلا الله وحده لا شريك لهاته، وأثشه أن محمداً

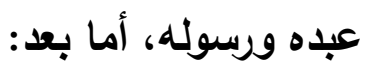

فإن حديث المرأة التي سألت النبي - - فئ-- في الحج، من الأحاديث التي حصل فيها اختلاف في الألفاظ والروايات، وتبعاً لذلك حصل الاختلاف

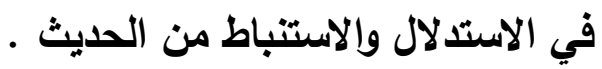

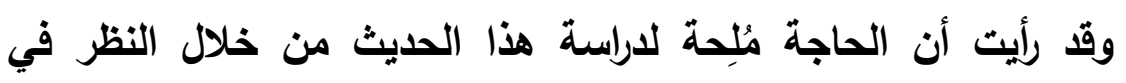

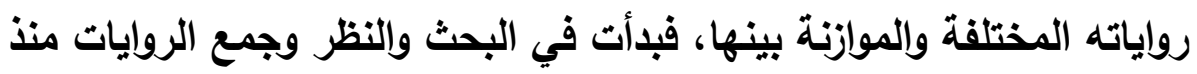

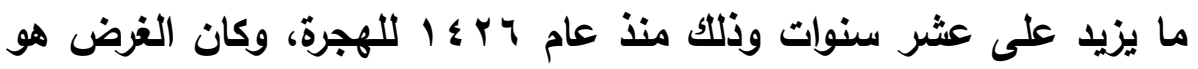
التوصل إلى نتيجة في استتباط الأحكام من هذا الحديث على اختلاف على ألفاظه وتعدد رواياته، وذلك من خلال دراسة حديثية مبينة على النظر في روايات

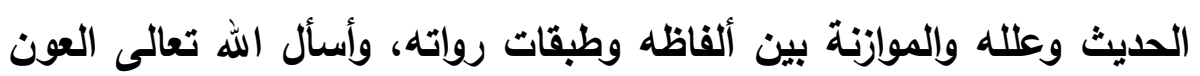

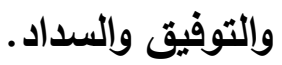

\section{أهمية البحث وأسباب اختياره:}

؛) اختلاف الألفاظ وتعدد الروايات في الحديث، أدى إلى الاختلاف في الاستدلال والاستنباط. الفاط. 
•) الموازنة بين الألفاظ والترجيح بينها يسهل معرفة الحق وييسر الترجيح بين أراء العلماء المختلفة .

7) الرغبة في إصابة الحق في معرفة الألفاظ الصحيحة للحديث بالموازنة

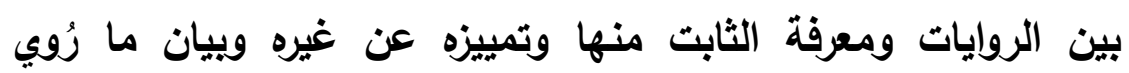

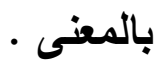

V لم أقف على من جمع الألفاظ والروايات ووازن بينها من خلال النظر في علم العلل وطبقات الرواة.

مشكية البمث:

توجد ألفاظ ثابتة اتفقت عليها معظم الروايات، وألفاظ أخرى مرجوحة لا

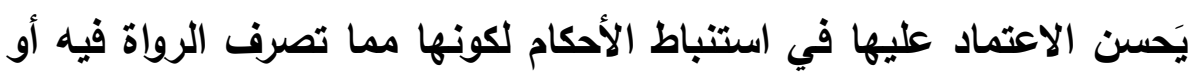
كونه مما روي بالمغنى، وتبعاً لألك اختلف العلماء في استتباط الأحكام

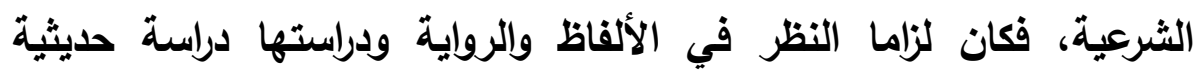

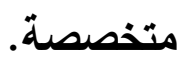

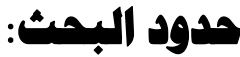

دراسة ألفاظ وروايات حديث الخثعية من كتب السنة دراسة حديثية، وييان أثر في استنباط الأحكام.

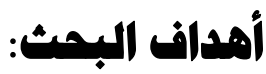

• بيان الألفاظ الصحيحة للحديث، بناء على دراسة حديثية مقارنة. 
• خدمة السنة النبوية بييان الألفاظ الصحيحة الثابتة وتمييزها عن غيرها. • • ل الإثكالات التي تتطق بهذا الحديث المهم.

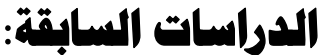

لم أجد من كتب بحثا خاصاً في دراسة اختلاف الألفاظ والروايات في حديث

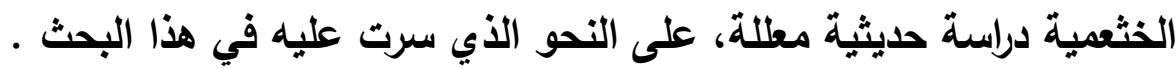
وقد وقفت على بحث أقرب إلى الجانب الفقهي وهو بعنوان: "تحرير القول في

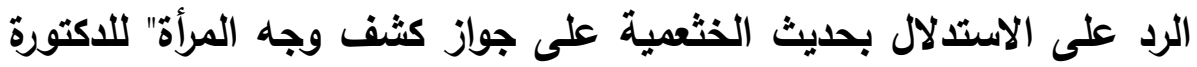
نعمات محمد الجعفري، وهو منشور في مجلة الدراسات الإسلامية بجامعة الأهل

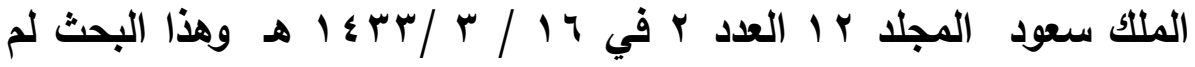
يخصص لدراسة روايات الحديث من ناحية حديثية إسنادية، حيث قصر عن

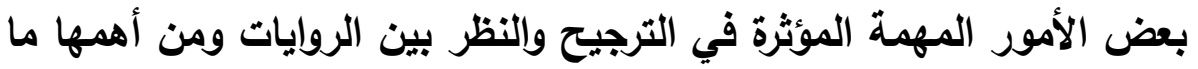
يلي: ( ) لم تبين الباحثة أرجح الروايات عن الصحابة لهذا الحديث ولم تثر إلى ولى ذلك إطلاقاً، وهي رواية الفضل نفسه صاحب القصة، وهذه الرواية أروان أخرجها الثيخان من طريق ابن جريج، عن الزهري، وهي رواية مؤثرة في الحكم

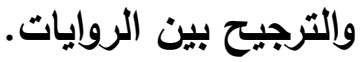

r) لم تتبع المنهج الحديثي في الحكم والترجيح بين الروايات عندما قالت: " اتفقت ألفاظ الحديث بمختلف رواياته على منع الرسول ابن عمده في مسارقته 
النظر إلى النساء، والإنكار عليه بالفعل"، وهذا حكمٌ عامٌ وغير دقيق؛ فُان رواية صاحب القصة لم يرد فيها شيء من ذلك إطلاقاً.

r) اعتمدت على الروايات عن ابن عباس في الترجيح بين الروايات مع أنه لم يحضر القصة أصلاً، كما نص على ذلك الحافظ ابن حجر وغيره. ع) لم تفعل النظر في طبقات الرواة عن الزهري، ولم تبين أثر ذلك في الترجيج.

•) لم تذكر علل روايات مهمة للحديث مثل رواية عبيد الله بن أبي زياد الرصافي عن الزهري وهي نسخة غير مشهورة، ومثل رواية أبي اليمان عن شعيب بن أبي حمزة عن الزهري وهي نسخة كذلك.

7) لم تبين رواية الجماعة ولم تستعمل علم العلل عند عرض الروايات المخالفة لها، ولم تشتفد من ذلك في الترجيح بين روايات الحديث وألفاظه. هذا وقد قسمت هذا البحث إلى مقدمة، ومبحثين، وخاتمة. الاقدمة: وفيها أهمية البحث، وأسباب اختياره، ومشكتته، وحدوده، وأهدافه، والدراسات السابقة.

المبمث الأهول: روايات الحديث في الصحيحين وغيرهما وفيه مطلبان: المطلب الأول: روايات الحديث في الصحيحين. المطلب الثاني: روايات الحديث خارج الصحيحين. 
المبمث الثاني: أثر اختلاف روايات الحديث وألفاظه في الاستباط والاستدلال وفيه مطلبان:

المطلب الأول: الموازنة بين روايات الدديث وألفاظه.

المطلب الثاني: مسألة كثف وجه المرأة. الخاتمة: وفيها أهم النتائج والتوصيات.

هذا وإني أسأل الله تعالى أن ينفع به، وأن يوفقتا للخير ولخدمة سنة نبيه -

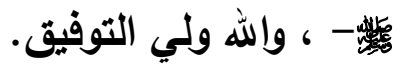




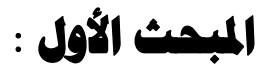

\section{روايات المديث في الصميصين وغيرهما .}

\section{الاملب الأول: روايات الصديث في الصميمين.}

أخرج البخاري -رحمه الله تعالى- هذا الحديث في خمسة مواضع من

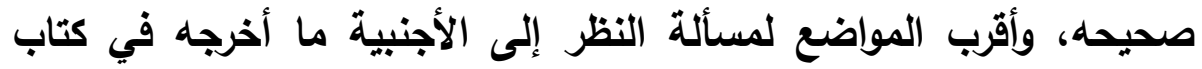
الاستئذان حيث قال - رحمه الله تعالى -:

حدثنا أبو اليمان، أخبرنا شعيب، عن الزهري قال: أخبرني سليمان بن

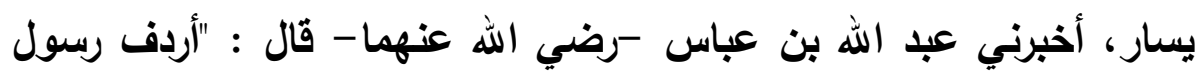
الله

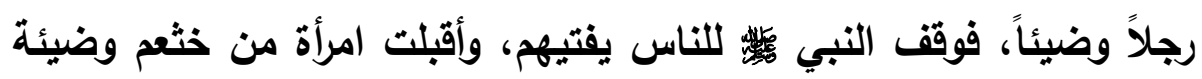
تستفتي رسول الله النبي

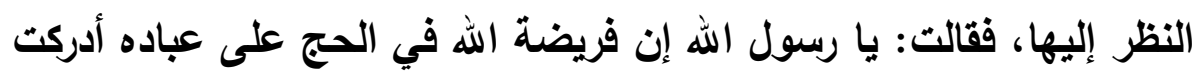
أبي شيخاً كبيراً لا يستطيع أن يستوي على الراحلة، فهل يقضي عنه أنه أن أحج أله

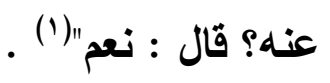

$$
\text { (1) صديح البخاري في كتاب الاستئذان، حديث رقم (ع \& ه ) }
$$


وقد جاء في هذا الحديث وصف المرأة بأنها "وضيئة "وأن حنهها أعجب

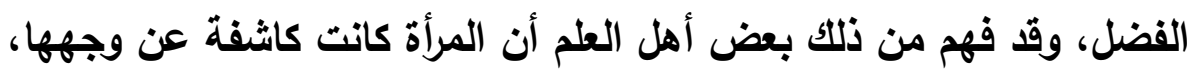

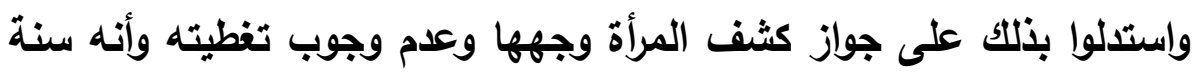

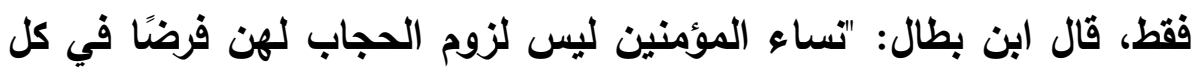

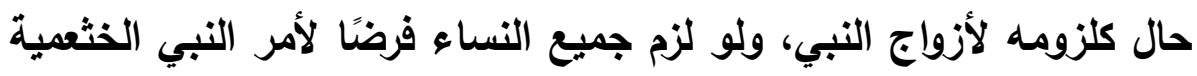

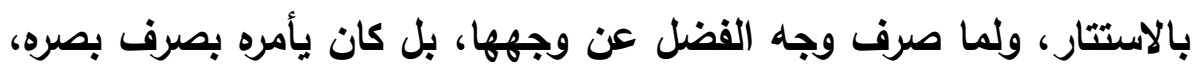

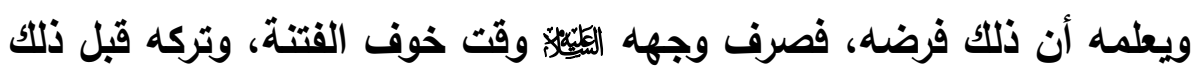

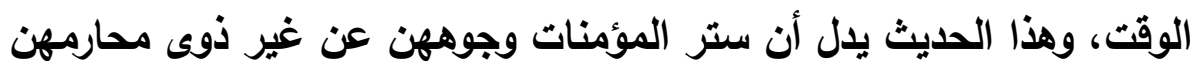

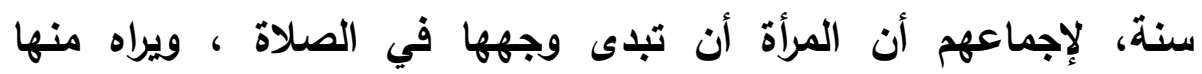

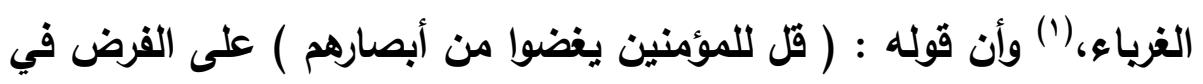

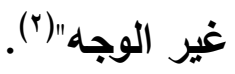

(1) لم يحصل الاجماع على ذلك فقد قال الإمام أحمد: "إذا صلت لا يرى منها

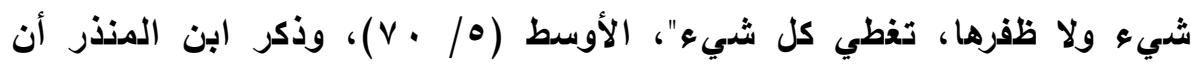

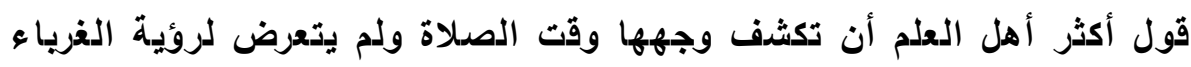

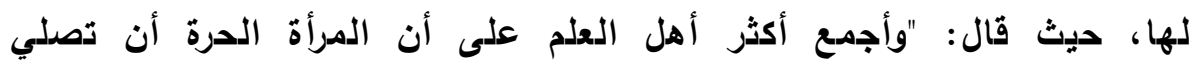

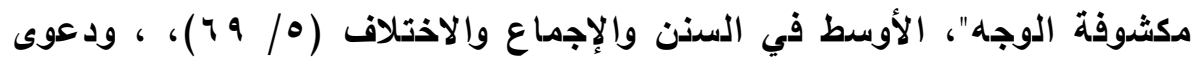

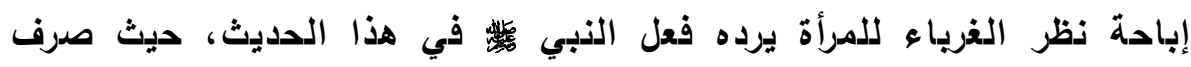

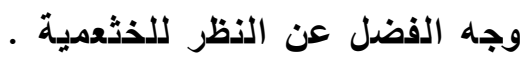

$$
\text { شرح صديح البخاري لابن بطال (1/9/9 (1) ) }
$$


وقال ابن حزم: "فلو كان الوجه عورة يلزم ستره لما أقرها لئليّلِّ على كشفه بحضرة الناس، ولأمرها أن تسبل عليه من فوق، ولو كان وجهها مغطى ما عرف ابن عباس أحسناء هي أم شوهاء فصح كل ما قتناه يقينًا "(1). أقول: ابن عباس لم يحضر القصة أصلاً كما سيأتي، وهنا عدة تساولات يمكن من خلالها النظر في اختلاف أهل العلم والترجيح بين أقوالهم، فهل وردث هذه اللفظة في الروايات الأخرى للحديث؟ وهل هي مما روي بالمعنى أم لا ؟ وهل يصح الاستدلال بها على جواز كشف المرأة وجهها ؟ وعلى تقدير ثبوت كثف الخثعمية وجهها فهل كان ذلك مقصوداً أم لا؟ وهل هناك احتمالات أخرى يمكن تفسير الحديث في ضوئها، وعلى تقدير كشف وجهها فهل كان لأجل الإحرام أم لا ؟ وهل في ذللك حجة لمن استدل على جواز

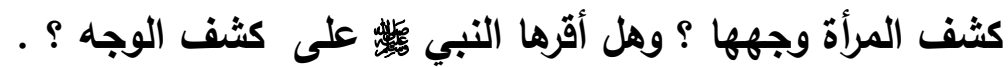
ولبيان ذلك لابد من دراسة روايات الحديث والموازنة بينها . أولاً: دوايات المديبث في المصيشين : مدار هذا الحديث في الصحيحين على الزهري يرويه عن سليمان بن يسار، عن ابن عباس -رضي الله عنهما- . 


\section{روايات المديث في صميج البناري :}

أخرج البخاري الحديث في خمسة مواضع في صحيحه عن خمسة من الرواة

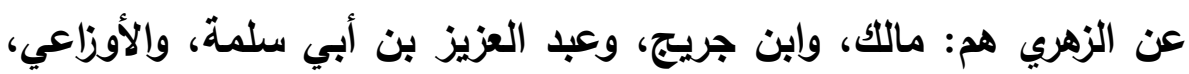
وشعيب بن أبي حمزة، وتفصيل ذلك كما يلي: هائ وني 1- الرواية الأولىى : رواية مالك عن الزهري أخرجها البخاري من طريقين

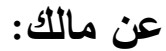

الأول : في كتاب الحج، باب وجوب الحج وفضله حيث قال: حثثنا عبد الله بن يوسف، أخبرنا مالك، عن ابن شهاب، عن سليمان بن يسار، عن عبد

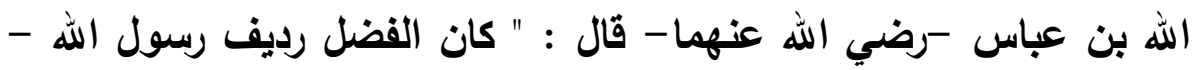

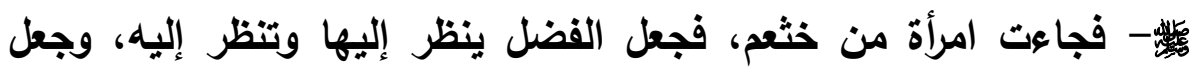
النبي

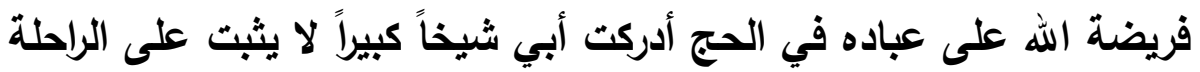

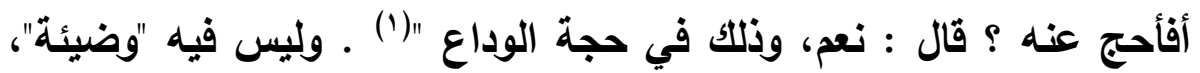

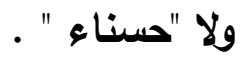

الثانيـ في كتاب الحج أيضا، باب حج المرأة عن الرجل، فقال : حدثنا عبد

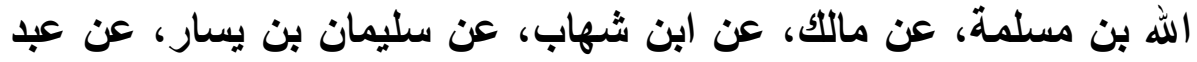

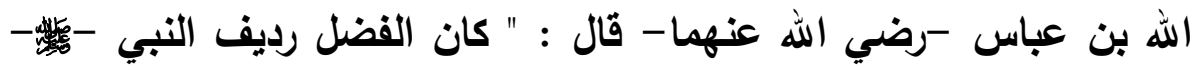

(") صحيح البخاري كتاب الدج، باب وجوب الحج وفضله حديث رقم (r 101) 
فجاءت امرأة من خثعم، فجعل الفضل ينظر إليها وتنظر إليه، فجعل التبي يصرف وجه الفضل إلى الثث الآخر، فقالت : إن فريضة الله أدلى أدركت أبي

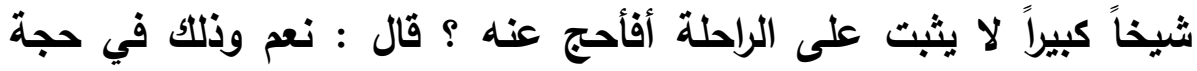

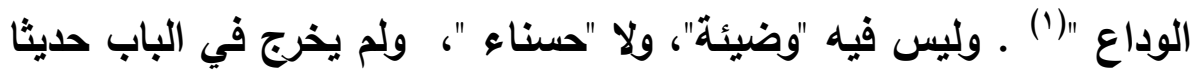

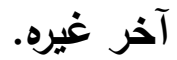

r- الرواية الثانية : رواية ابن جريج عن الزهري، أخرجها البخاري في كتاب جزاء الصيد، باب الحج عمن لا يستطيع الثبوت على الثى

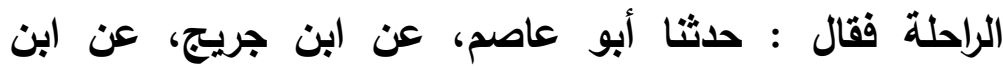
شهاب، عن سليمان بن يسار، عن ابن عباس، عن الفضل بن

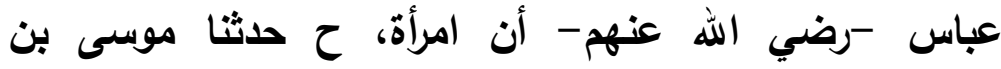

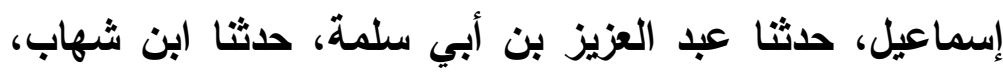
عن سليمان بن يسار، عن ابن عباس -رضي الله عنهما- قال : "جاهت امرأة من خثعم عام حجة الوداع قالت : يا رسول الله إن فريضة الله على عباده في الحج أدركت أبي شيخاً كبيراً لا

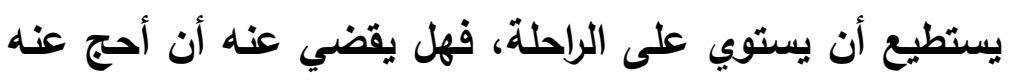

صديح البخاري كتاب الدج، باب حج المرأة عن الرجل، حديث رقم 
؟ قال نعم "(1) وليس فيه "وضيئة"، ولا "حسناء "، ولم يخرج في

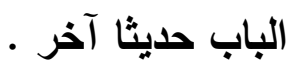

r- - الرولية الثالثة : رواية عبد العزيز بن أبي سلمة مع الرواية

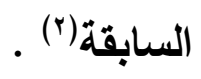

ع - الرواية الرابعة : رواية الأوزاعي أخرجها البخاري في كتاب المغازي، باب حجة الوداع فقال: حدثنا أبو اليمان، قال: حدثي شعيب، عن الزهري، وقال محمد بن يوسف: حدثنا الأوزاعي قال: أخبرني ابن شهاب، عن سليمان بن يسار، عن ابن عباس -

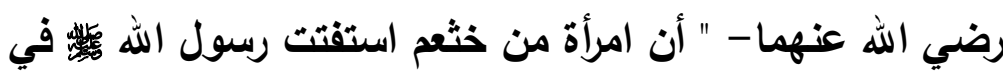

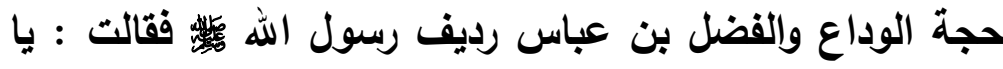
رسول الله إن فريضة الله على عباده أدركت أبي شيخا كبيراً لا يستطيع أن يستوي على الراحلة، فهل يقضي أن أحج عنه؟ قال: نعم "() وليس فيه "وضيئة"، ولا "حسناء "، وترتيبه الخامس في أني أحاديث الباب وقد أخرج بعده خمسة عشر حديثاً في نفس الباب.

صديح البخاري كتاب جزاء الصيد، باب الحج عمن لا يستطيع الثبوت

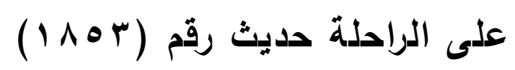

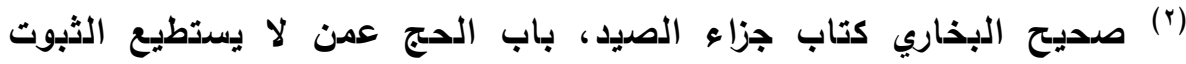

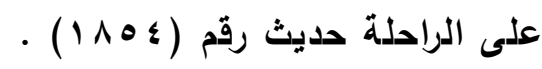

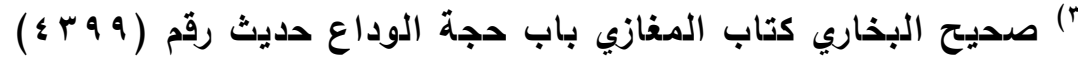


ه- - الرواية الخامسة : رواية شعيب بن أبي حمزة أخرجها البخاري في موضعين الأول مقرونة برواية الأوزاعي السابقة بلفظ حدثا أبو اليمان قال حدثي شعيب عن الزهري، وليس فيها وضيئة، والظاهر أن البخاري أورد لفظ رواية الأوزاعي عن الزهري ويلاحظ هنا أن رواية أبي اليمان عن شعيب جاءت بصيغة التحديث .

ثم أخرجها في موضع آخر في كتاب الاستئذان باب قول الله تعالى : (يا أيها الأين آمنوا لا تلخلوا بيوتا غير بيوتكم ...) الآية فقال: حدثنا أبو اليمان، أخبرنا شعيب، عن الزهري الحديث ... وفيها لفظة وضيئة كما تقدم (1)، ويلاحظ هنا أن رواية أبي اليمان عن شعيب بن أبي حمزة هنا جاء بصيغة أخبرنا بخلاف الموضع الأول الأي لم ترد فيه هذه اللفظة، ولعل هذا يدل على أن هذا الحديث روي عن أبي اليمان عن شعيب بن أبي حمزة بالمعنى

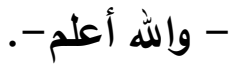

ثم أورد بعده حديث أبي سعيد الخدري -رضي الله عنه- في حق الطريق، وفيه أن الصحابة قالوا: "وما حق الطريق؟ قال : "غض البصر، وكف الأنى، ورد السلام، والأمر بالمعروف والنهي عن المنكر "(ץ) .

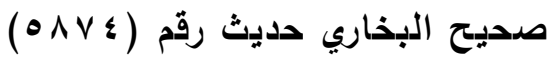

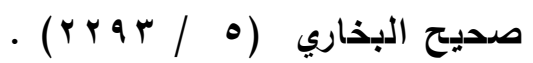




\section{ثانيا: روايات المديث في صميح مسلم:}

أخرج مسلم الحديث في صحيحه من طريقين عن الزهري، من طريق مالك

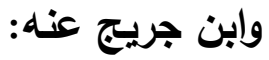

فأما الأول: فأخرجه من طريق مالك، عن الزهري، في كتاب الحج، باب الحج

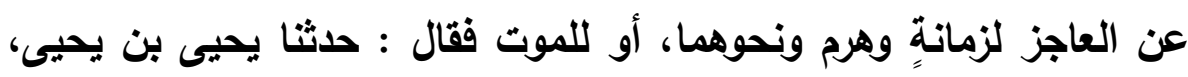
قال قرأت على مالك،، عن ابن شهاب، عن سليمان بن يسار، عن عبد الله بن عباس أنه قال: " كان الفضل بن عباس رديف رسول الله في في فياعته امرأة من خثعم تستفتيه، فجعل الفضل ينظر إليها وتنظر إليه، فجعل رسول الله يصرف وجه الفضل إلى الثق الآخر، قالت : يا رسول الله إن فريضة الله على عباده في الحج أدركت أبي شيخاً كبيراً لا يستطيع أن يثبت على الراحلة أفأحج عنه ؟ قال نعم، وذلك في حجة الوداع "(1) . وأما الثاني: فأخرجه من طريق ابن جريج عن الزهري بعد العديث السابق، فقال: حدثي علي بن خشرم، أخبرنا عيسى، عن ابن جريج، عن ابن

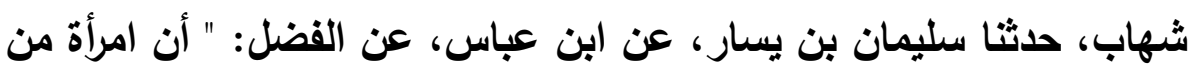

(1) صحيح مسلم كتاب الدج ، باب الدج عن العاجز لزمانه وهزم وندوهما أو

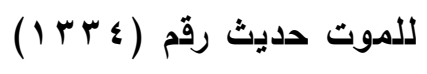


خثعم قالت : يا رسول الله إن أبي شيخ كبير عليه فريضة الله في الحج وهو

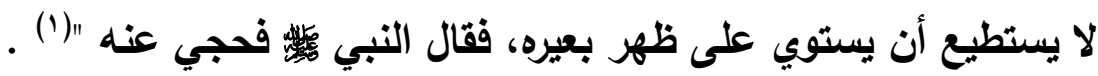

(') صحيح مسلم كتاب الحج ، باب الحج عن العاجز لزمانه وهرم وندوهما أو

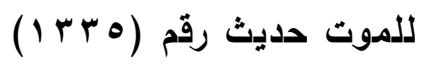




\section{الاملب الثاني: الروايات عن الزهري خارة الصميشين.}

أولاً : الروايات عن الزهري في السنن ومسند الإمام أحمد التي ليس فيها

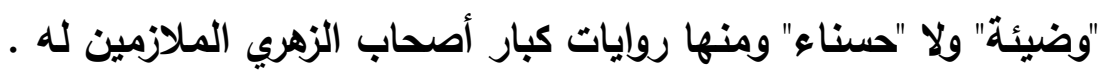
( ) رواية معمر، عن الزهري، عن سليمان بن يسار عن (بن عباس، عن

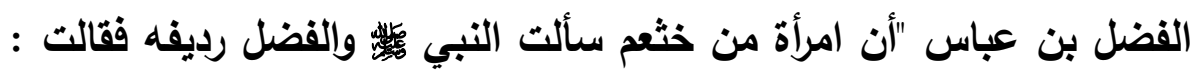
يا رسول الله إن فريضة الله في الحج على عباده أدركت أبي وهو شيخ أنيخ كبير

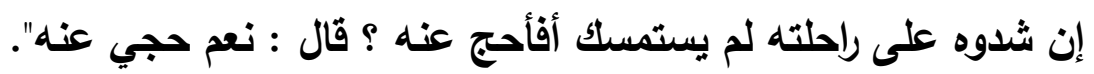
رواه أحمد(')، وأبو يعلى(ץ) من طريق عبدالرنلق عن معمر، ورواه

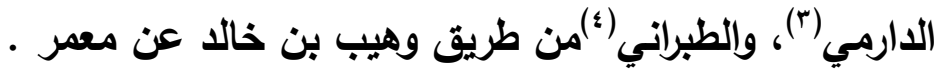
ومعمر من كبار أصحاب الزهري الملازمين له، من أصحاب الطبقة الأولى . وقد أخرج الترمذي حديث الفضل هذا من طريق ابن جريج عن الزهري ثم

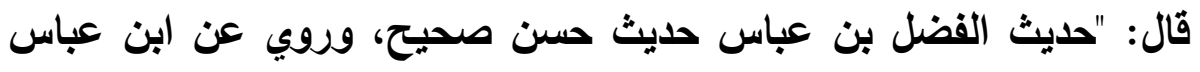

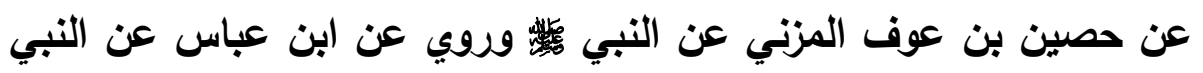

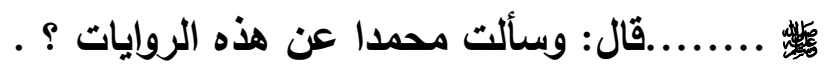

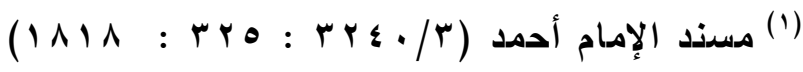

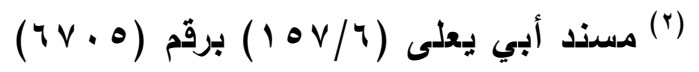

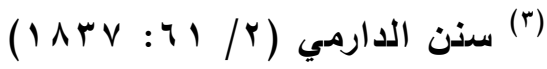

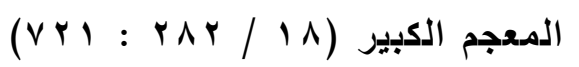


فقال: أصح شيء في هذا الباب ما روى ابن عباس عن الفضل بن عباس

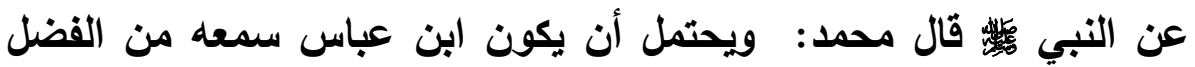
وغيره عن النبي

منهة"(')

r باية سفيان بن عيينة، عن الزهري، عن سليمان بن يسار، عن ابن

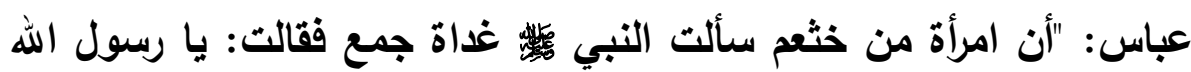

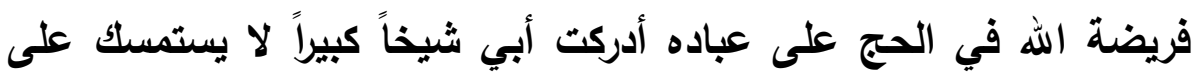
الرحل أفأحج عنه؟ قال : نعم " أخرجها أحمد وإلنسائي () . r) رواية أيوب السختياني، عن الزهري، عن سليمان بن يسار، عن ابن

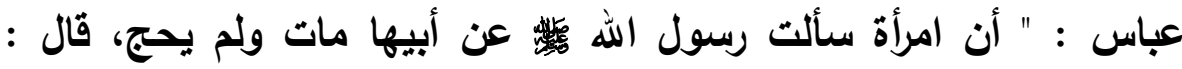

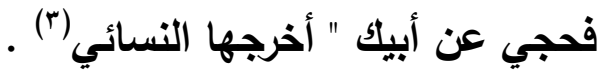
ثانياً: الروايات عن الزهري خارج السنن ومسند الإمام أحمد التي ليس فيها

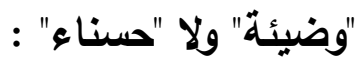

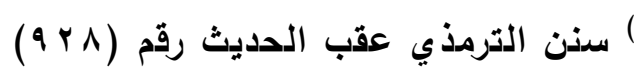

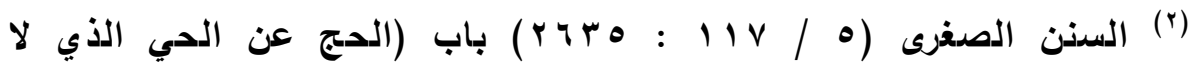

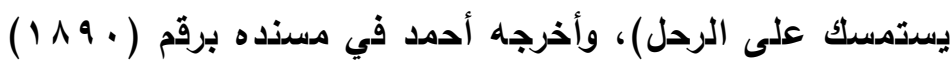

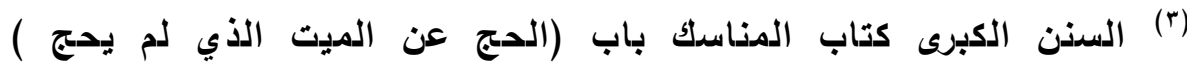

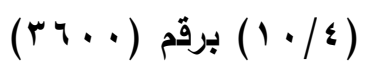


؛) رواية هشام بن عروة، عن الزهري، عن سليمان بن يسار، عن ابن

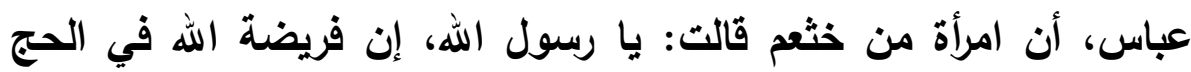

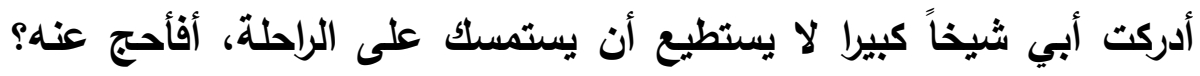

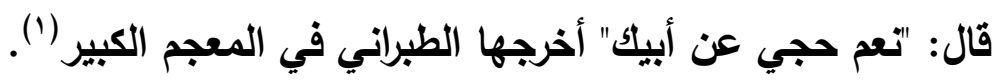
•) رواية الليث، عن ابن شهاب، عن سليمان بن يسار، عن ابن عباس،

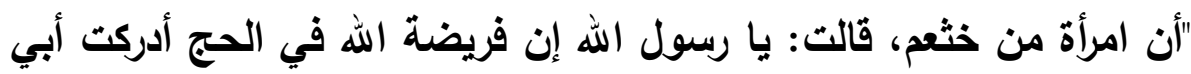

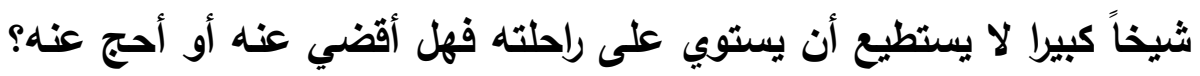

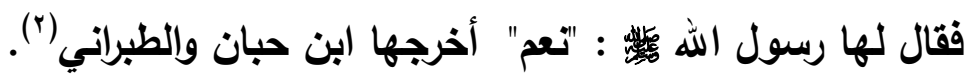
") رواية عبد الرحمن بن إسحاق، عن الزهري، عن سليمان بن يسار، عن

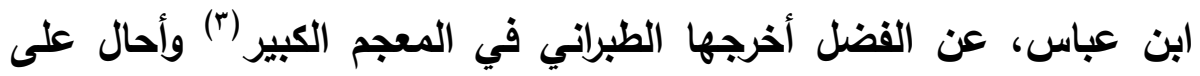

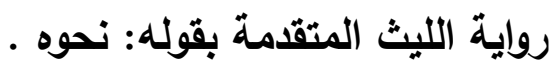

(V رواية أيوب بن موسى ابن عمرو بن سعيد بن العاص(؛)، أخرجها

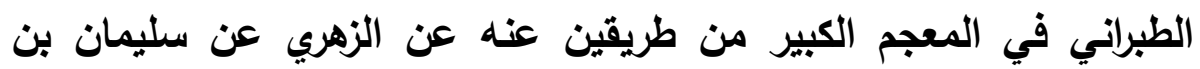

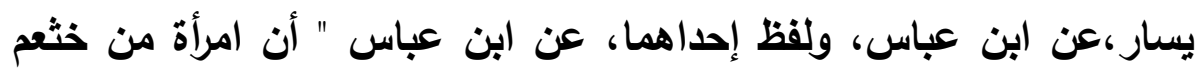

$$
(\vee r \varepsilon: r \wedge \uparrow / 1 \wedge)
$$

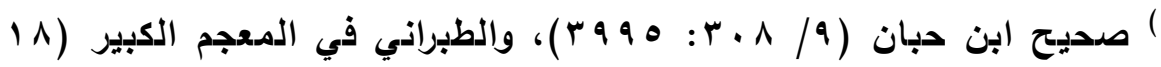

$$
\begin{aligned}
& \text { ( } \vee r): r \wedge 0 / \\
& (\vee r r: r \wedge \tau / 1 \wedge)^{(r)} \\
& \text { () وهو: ثقة كما في التقريب (ترجمة رقم: }
\end{aligned}
$$


استفتت رسول الله

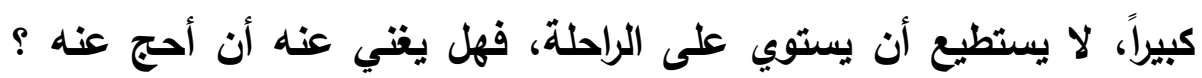

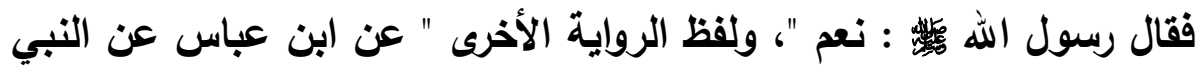

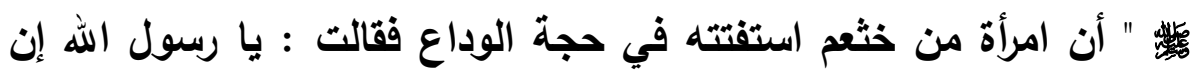

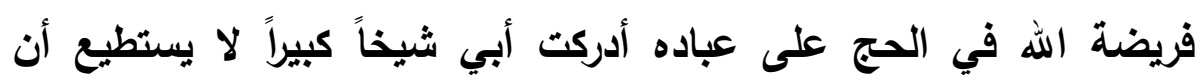

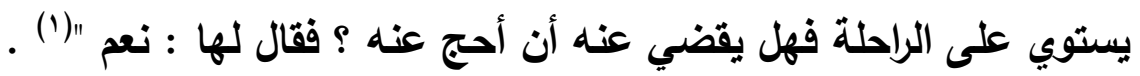

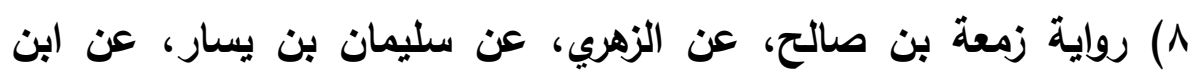

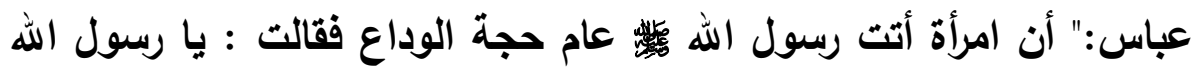

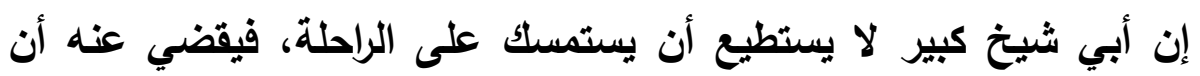

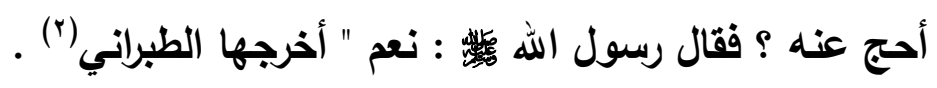
9) رواية قرة بن عبد الرحمن عن الزهري، عن سليمان بن يسار، عن ابن

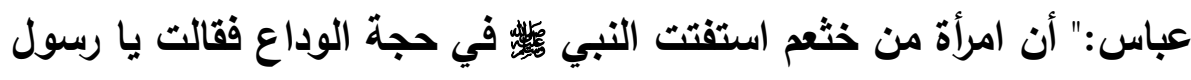

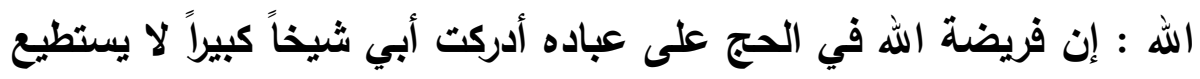

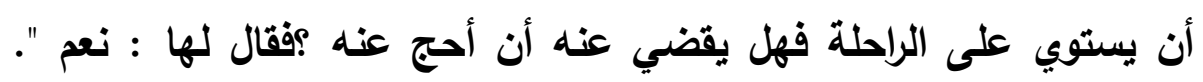

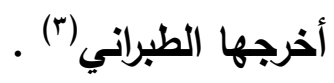

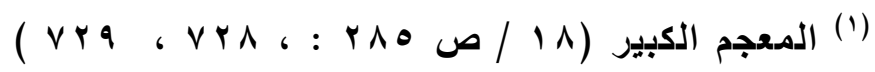

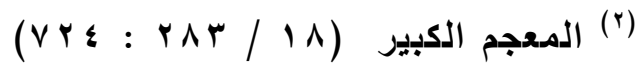

$$
\begin{aligned}
& \text { ( المعجم الكبيز ( }
\end{aligned}
$$


ثالثاً: الروايات التي فيها وصف المرأة بأنها (وضيئة) أو ( حسناء) عن

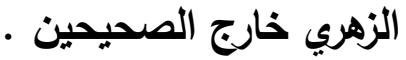

وققت على ثلاث روايات خارج الصحيحين فيها وصف المرأة بأنها كانت وضيئة أو حسناء وهي كما يلي: تلاث روات كارج

1) رواية الأوزاعي، أخرجها الطبراني في المعجم الكبير فقال: حدثا مطلب بن شعيب الأزدي، ثنا عبد الله بن صالح، حدثا الهقل بن زياد(')، حدثي الأوزاعي، حدثني الزهري، حدثي سليمان بن يسار أن عبد الله بن عباس قال : " أردف رسول الله وكان الفضل رجلا وضيئا، فوقف رسول الله لط: للناس يفتيهم، فأقبلت امرأة من خثع وضيئة تستقتي رسول الله حسنها، فالتفت رسول الله علد،، والفضل ينظر إليها، فأخلف يده، فأخذ بذقن الفضل يعدل وجهه عن النظر إليها، فقالت تلكك: يا رسول الله، إن فريضة الله في الحج على عباده أدركت أبي شيخاً كبيراً، لا يستطيع أن يستوي على لهن

هقل بكسر أوله وسكون القاف ثم لام ابن زياد السكسكي بمهملتين

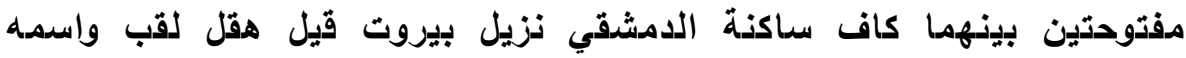

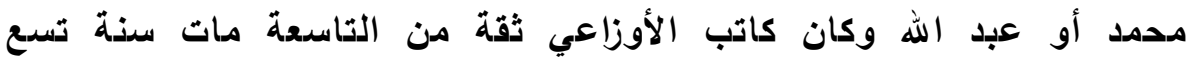

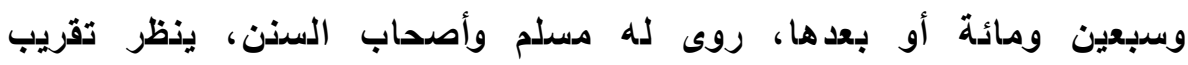

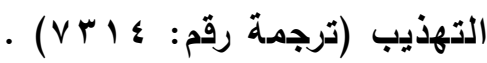


الراحلة، فهل يقضي أن أحج عنه؟ فقال لها رسول الله

(1)"

r) رواية عُبيَد الله بن أبي زياد الرُّصافيّ، أخرجها الطبراني في المعجم الكبير فقال: حدثنا أبو أسامة الحلبي ثنا حجاج بن أبي منيع الرصافي ثنا جدي(؟) عن الزهري عن سليمان بن يسار أن عبد الله بن عباس قال : " أردف رسول الله رجلا وضيئا، فوقف رسول الله كئد للناس يفتيهم، فأقبلت امرأة من خثعم وضيئة تشتقتي رسول الله فالتفت رسول الله كئد والفضل بيظر إليها، فأخلف بيده بذقن الفضل، فعدل وجهه عن النظر إليها، فقالت تلك الخثعمية: يا رسول الله، إن فريضة الله في الحج، أدركت أبي شيخاً كبيراً لا يستطيع أن يستوي على الراحلة، فهل يقضي عنه أن أحج عنه؟ فقال لها رسول الله

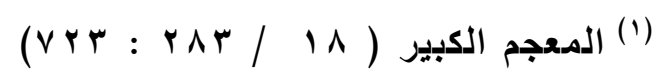

(r) حجاج بن أبي منيع يوسف وقيل عبيد الله بن أبي زياد الرصافي ثقة كما

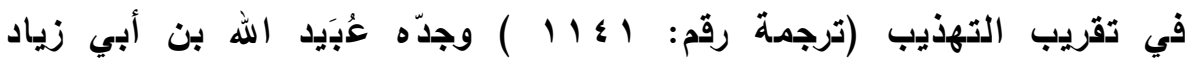

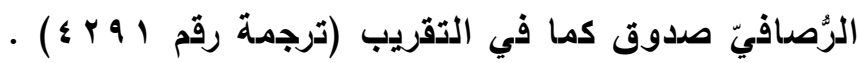

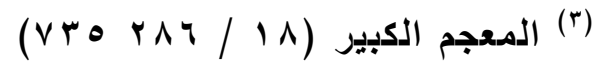


و عُبَيد الله بن أبي زياد الرُصافيّ بروي عن الزهري نسخة كبيرة ولكنها ليست

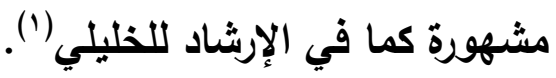

r) رواية صالح بن كيسان عن الزهري، أن سليمان بن يسار، أخبره أن ابن عباس، أخبره: " أن امرأة من خثعم استفتت رسول الله بك في في حجة الوداع، والفضل بن عباس رديف رسول الله في الحج على عباده أدركت أبي شيخا كبيرا، لا بستوي على الراحلة، فهل

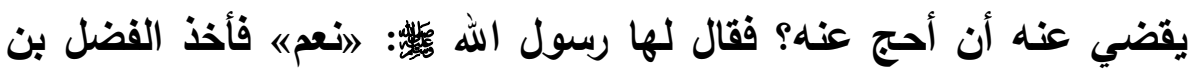
عباس يلتفت إليها، وكاتت امرأة حسناء، وأخذ رسول الله

\section{وجهه من الثق الآخر" (؟).}

من خلال التأمل في الروايات السابقة يلاحظ ما يلي: أولاً : رواية الهِهْل بن زياد عن الأوزاعي معلولة لمايلي :

(1) تهذيب الكمال في أسدماء الرجال (0/ ) ج ؛ ترجمة حجاج بن أبي مذيع

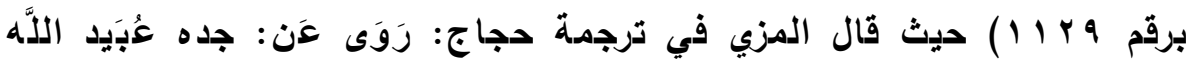

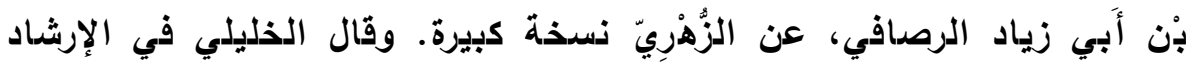

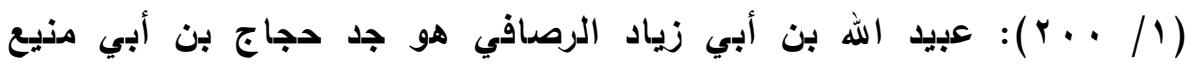

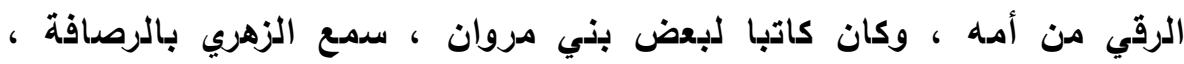

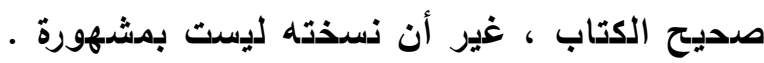

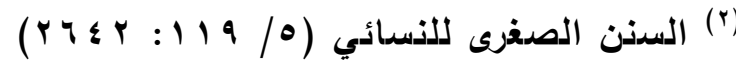


( ) الراوي عن الهقل هو عبد الله بن صالح أبو صالح كاتب الليث متكلم فيه .

r) مخالفتها للروايات الصحيحة عن الأوزاعي في صحيح البخاري(')، وسنن (النسائي (r) r) مخالفتها لعامة الروايات عن الزهري من طرق أصحابه الملازمين له فإن هذه اللفظة لم ترد فيها كما تقدم . ثالثاً: يلاحظ أن الروايات التي فيها لفظة (وضيئة)، نسخ فرواية أبي اليمان

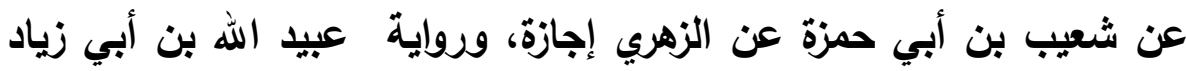

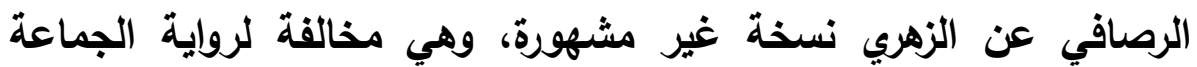

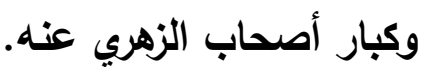

$$
\begin{aligned}
& \text { (1) تقدم سياقها في صحيح البخاري في التخريج . (1) التون }
\end{aligned}
$$

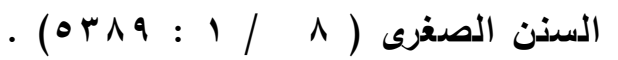

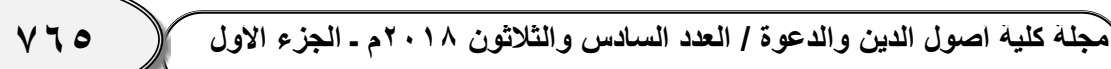




\section{الابمث الثاني: \\ أثر اختلاف روايات المديث وألفاظه في الاستنباط والاستدلال \\ المطلب الأول: الموازنة بين روايات المديث وألفاظه.}

من خلال التأمل في الروايات السابقة للحديث يلاحظ أن مدار الحديث في الصحيحين على الزهري يرويه عن سليمان بن يسار، عن ابن عباس، وقد

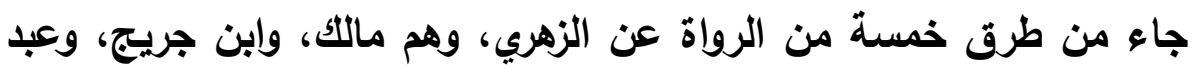
العزيز بن أبي سلمة، والأوزاعي، وشعيب بن أبي حمزة، وكلهاء منها أخرجها

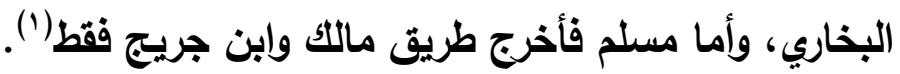
كما أن جميع الروايات في الصحيحين جاءت من حديث ابن عباس من

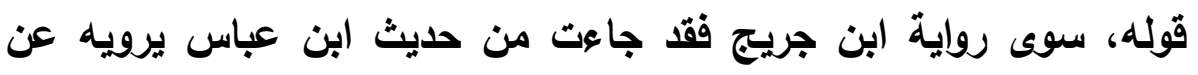

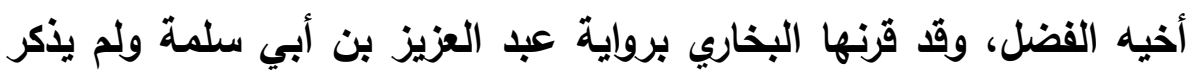

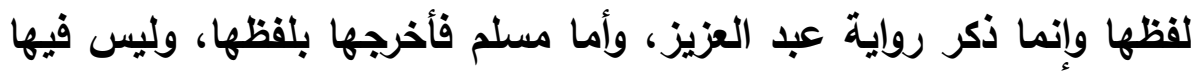
أن المرأة كانت وضيئة أو أنها حنداء أو أن الفضل كان ينظر إليها أو أو أنه

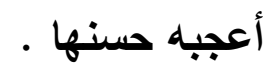

وقد رجح البخاري رواية ابن عباس عن أخيه الفضل على غيرها، قال

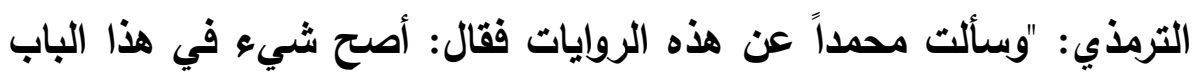

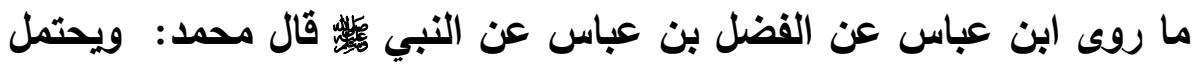
(1) الروايات المذكورة في الصحيدين، وقد تقدم تخريجها. 
أن يكون ابن عباس سمعه من الفضل وغيره عن النبي

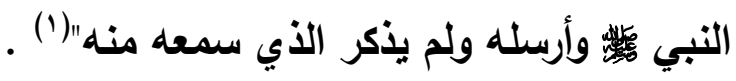

ولم يرد في رواية الفضل أن الخثعمية كانت كاشفة عن وجهها أو أنها كانت حسناء أو وضيئة أو أن الفضل كان ينظر إليها أو أنه أعجبه حسنها. كما يظه أن ألفاظ الحديث في الصحيحين لم يرد فيها (حسناء) ولا (وضيئة) إلا في موضع واحد فقط من رواية أبي اليمان عن شعيب بن أبي

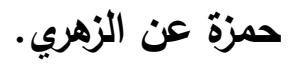

وأما الروايات في صحيح مسلم فلا يوجد فيها وصف المرأة بأنها كانت وضيئة ولا حسناء، كما أنه ل لا يوجد في ألفاظ الحديث في الصحيحين

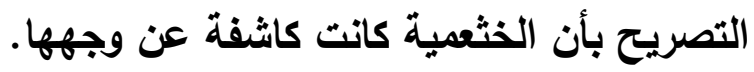
وقد جاء هذا الحديث من طرق كثيرة عن الزهري في الصحيحين وخارجهما، ولم ترد فيه لفظة وضيئة في الصحيحين إلا في موضع واحد فقط من رواية أبي اليمان عن شعيب بن أبي حمزة. ويظهر من خلال النظر في الروايات أن الرواية الوحيدة التي جاهت فيها

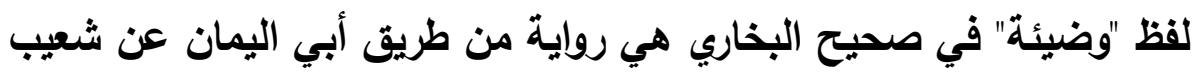

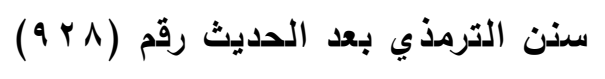


بن أبي حمزة وقد جاءت بصيغة الإخبار، وقد ذكر الإمامان أحمد وأبو زرعةرحمهما الله تعالى - أن رواية أبي اليمان عن شعيب بن أبي حمزة إجازة('). وهنا يجب التتبيه إلى أن دراسة الروايات التي ظاهرها الاختلاف أو التعارض لا يسوغ الطعن في السنة التبوية ولا يقاح في الصحيحين؛ لأن المقصود هو بيان الراجح فيما ظاهره التعارض لتمييز ما روي بالمعنى من غيره ولا سيما عند استتباط الأحكام الفقهية.

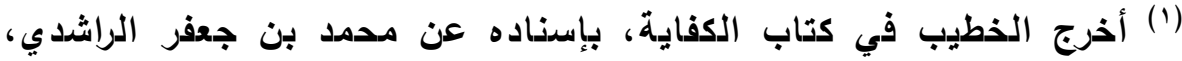
عن أبي بكر الأثرم : سدمعت أبا عبد الله، وسئل عن أبي اليمان، وكان الذيان الذيان

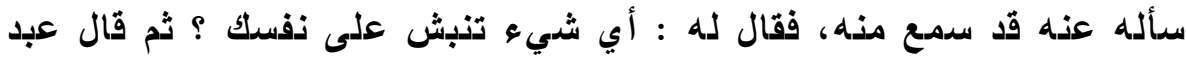
الله: هو يقول أخبرنا شعيب، واستحل ذلك بشيء عجيب. قال أبو عبد الله :

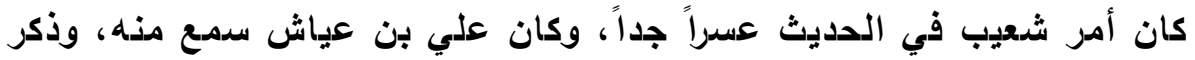

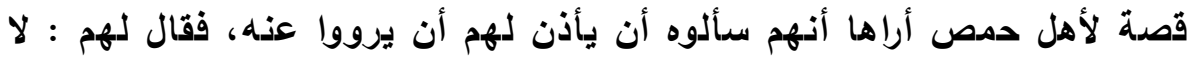

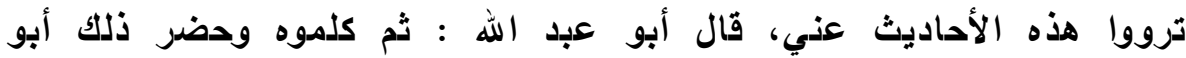

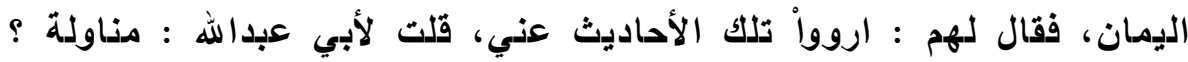

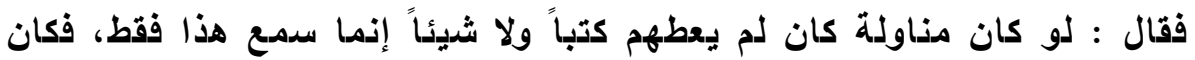

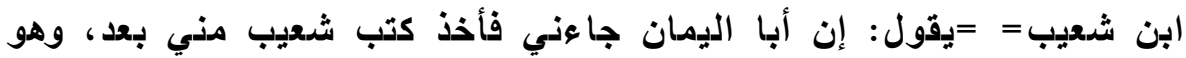

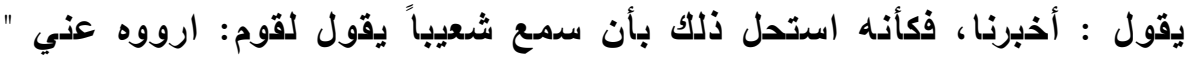

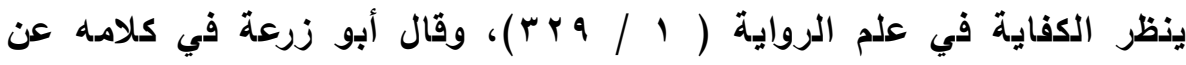

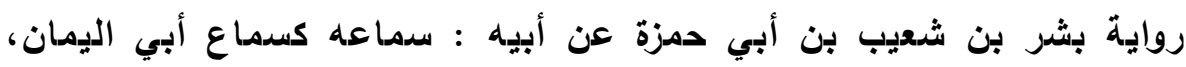

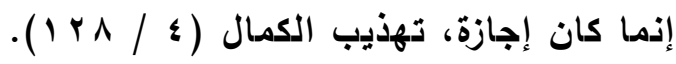


قال ابن تيمية معلقاً على اختلاف الألفاظ في قصة جمل جابر: " الغلط لا يكون في قصة طويلة متنوعة وإنما يكون في بعضها، فإذا روى هذا قصة طويلة متنوعة ورواها الآخر مثلما رواها الأول من غير مواطأة امتنع الغلط في جميعها كما امتتع الكذب في جميعها من غير مواطأة، ولهذا إنما يقع في مثل ذلك غلط في بعض ما جرى في القصة مثل حديث اشتراء التبي صلى الله عليه وسلم البعير من جابر فإن من تأمل طرقه علم قطعا أن الحديث صحيح وإن كانوا قد اختلفوا في مقدار الثمن، وقد بين ذلك البخاري في صحيحه فإن جمهور ما في البخاري ومسلم مما يقطع بأن النبي صلى الله عليه وسلم قاله؛ لأن غالبه من هذا النحو؛ ولأنه قد تلقاه أهل العلم بالقبول

والتصديق "(1)

وأما رواية ابن عباس - رضي الله عنهما -فإنما رواها بواسطة الفضل، ولم يحضر القصة قال ابن حجر: " وإنما رجح البخاري الرواية عن الفضل، لأنه كان ردف النبي

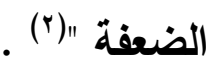

وقال الشيخ محمد الأمين الشنقيطي في أضواء البيان : " عبدالله بن عباس رضي الله عنهما الأي روي عنه هذا الحديث لم يكن حاضراً وقت نظر أخيه إلى المرأة، ونظرها إليه لما قدمنا من أن التبي رئس

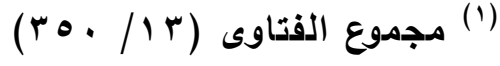

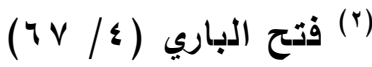


مزدلقة إلى منى في ضعفة أهله، ومعلوم أنه إنما روى الحديث المذكور من طريق أخيه الفضل، وهو لم يقل له : إنها كانت كاشفة عن وجهها"(1) . . وقد روي هذا الحديث من غير طريق ابن عباس رضي الله عنهما، فروي

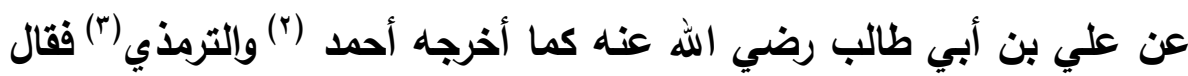

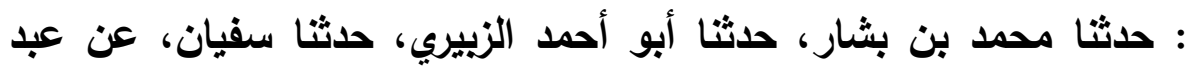
الرحمن بن الحارث بن عياش بن أبي ربيعة، عن زيد بن بن علي، عن أن أبيه،

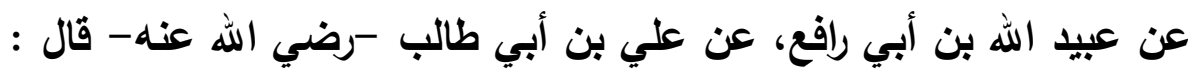

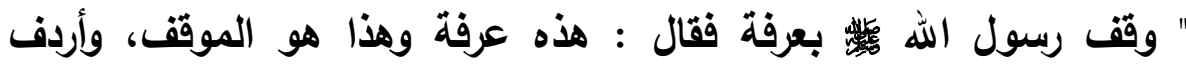

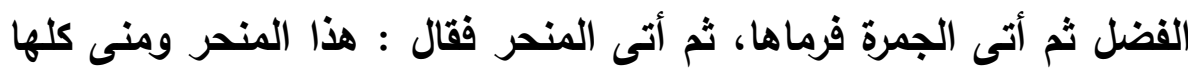

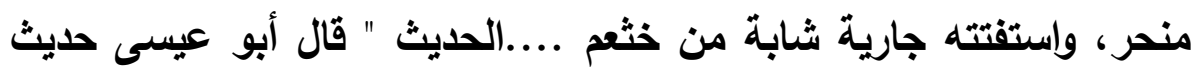
علي حديث حسن صحيح لا نعرفه من حديث على إلا من هذا الوجه . . انتهى. فليس فيه (وضيئة) ولا (حسناء) ولا ما يدل على أن المرأة كاتت كاشفة عن وجهها.

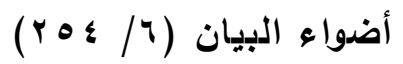

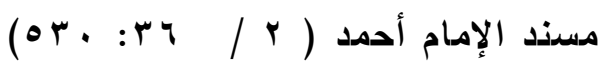

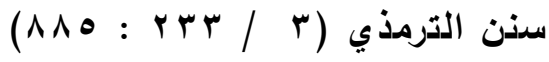


وقد ذكر الحافظ ابن حجر أنه وقع اختلاف على سليمان بن يسار في أن السائل رجل أو امرأة، ويين أنه نظر في الروايات فرجح أن السائل في أول

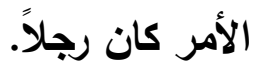

فقال -رحمه الله تعالى - : "وهذا الاختلاف كله عن سليمان بن يسار فأحبينا

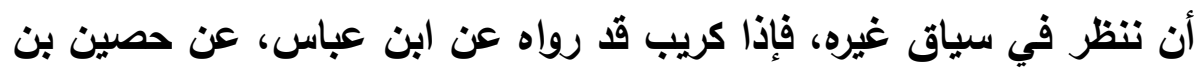

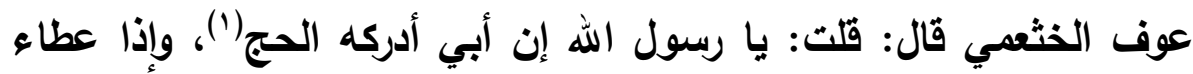

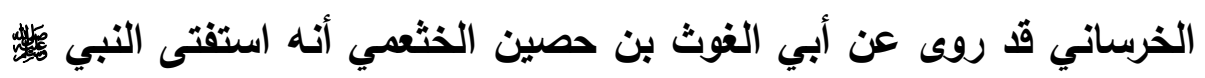

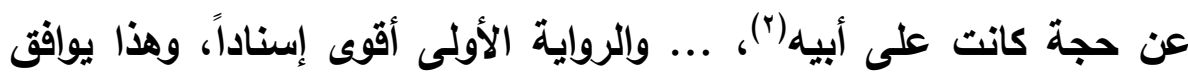
رواية هشيم في أن السائل عن ذلك رجل سأل عن أبيه(")، ويوافقه ما روى الته

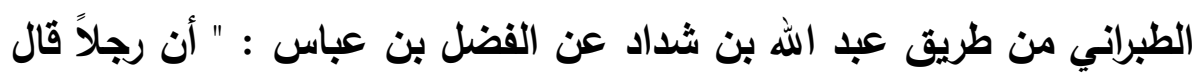

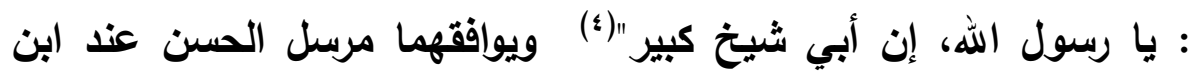
خزيمة فإنه أخرجه من طريق عوف عن الحسن قال : بلغني " أن رسول الله

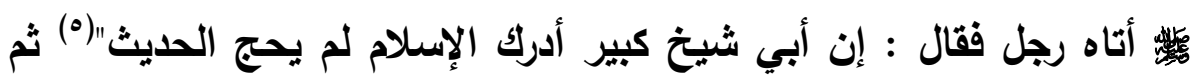
ساقه من طريق عوف عن محمد بن سيرين عن أبي هريرة قال مثله، إلا أنه

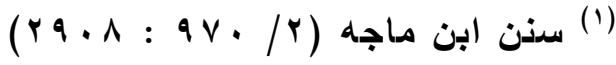

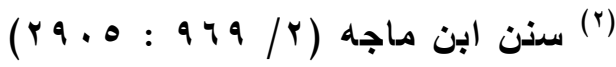

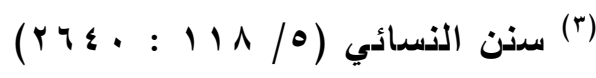

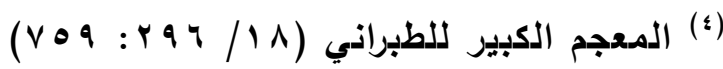

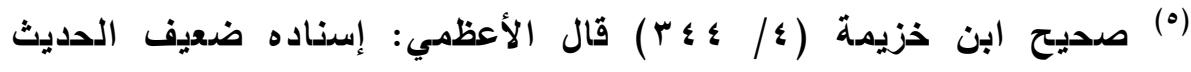

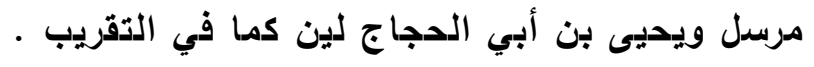


قال : "أن السائل سأل عن أمه " قلت('): وهذا يوافق رواية ابن سيرين أيضا عن يحيى بن أبي إسحاق كما تقدم، والذي يظهر لي من مجموع هذه الطرق أن السائل رجل وكاتت ابنته معه فسألت أيضاً والمسئول عنه أبو الرجل وأمه جميعا" انتهى كلامه رحمه الله (ץ). وهذا الجمع حسن ولكن الراجح أن السائل امرأة وأنها كانت تسأل عن أبيها كما في روايات الثقات الحفاظ عن الزهري وغيره. المطلب الثاني: مسألة كشف وجه المرأة.

جاء في الحديث وصف المرأة بأنها "وضيئة " وفي رواية أنها "حسناء"() وهذه الألفاظ ونحوها لا يلزم منها أن المرأة كانت كاشفة عن وجهها، فقد توصف المرأة بالحسن والجمال والوضاءة بمجرد النظر إلى عينيها أو شيء مما ظهر من جسمها أو قوامها، وذلك أمر معلوم عند العرب قال التنوخي

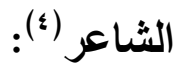

$$
\begin{aligned}
& \text { (1) (القائل ابن حجر (1) } \\
& \text { (r) }
\end{aligned}
$$

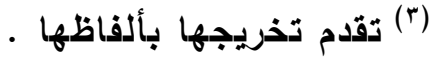

(؛) هو : أبو علي التذوخي القاضي أبو علي المدسن بن أبي القاسم علي

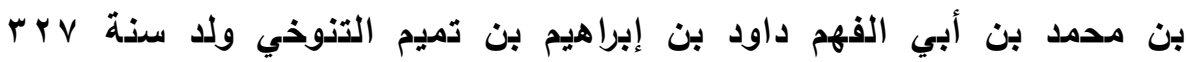

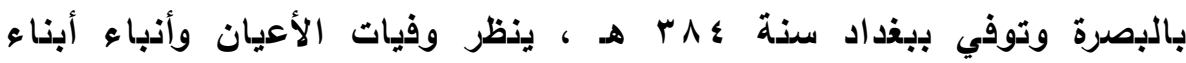

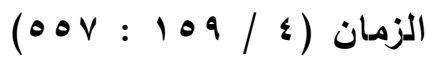


قل للمليحة في الخمار المذهب أفسدت نسك أخي التقي المترهب

نور الخمار ونور خدك تحتــــهـ عجبا لوجهك كيـــــــ لم يتلكهب وجمعت بين المذهبين فلم يكن للحسن عن ذهبيهما من مـــهب

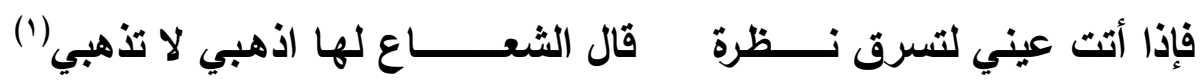
قال القاضي عياض : " وقوله إن كانت جارتك أوضأ منك أي أحسن، وكذا

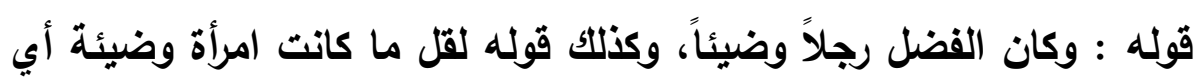

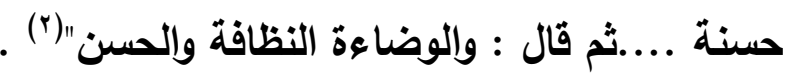

فذكر القاضي أن الوضاءة تدل على النظافة والحسن ولم يتعرض لذكر

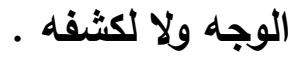

وقال الثنقيطي في أضواء البيان "ليس في شيء من روايات الحديث

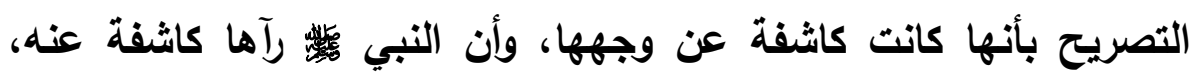
وأقرها على ذلك بل غاية ما في الحديث أنها كانت وضيئة، وفي بعض روايات الحديث : أنها حسناء، ومعرفة كونها وضيئة أو حسناء لا يستلزم

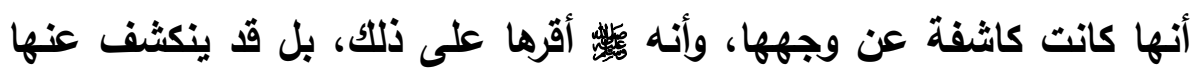
خمارها من غير قصد، فيراها بعض الرجال من غير قصد كثفها عن وجهها،

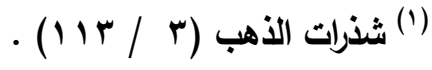

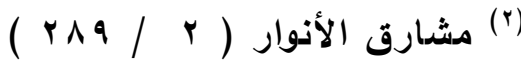


كما أوضحناه في روئية جابر سفعاء الخدين . ويحتمل أن يكون يعرف حسنها قبل ذلك الوقت لجواز أن يكون قد رآها قبل ذلك وعرفها، ومما يوضح هذا أن عبد الله بن عباس رضي الله عنهما الذي روي عنه هذا الحديث لم يكن حاضرا وقت نظر أخيه إلى المرأة، ونظرها إليه لما قدمنا من أن النبي لهائ قدمه بالليل من مزدلفة إلى منى في ضعفة أهله، ومعلوم أنه إنما روى إلى الحديث المذكور من طريق أخيه الفضل، وهو لم يقل له : إنها كانت كاثفة هئ عن وجهها واطلاع الفضل على أنها وضيئة حسناء لا يستلزم السفور قصدا لاحتمال أن يكون رأى وجهها، وعرف حسنه من أجل انكثاف خمارها من غير قصد منها، واحتمال أنه رآها قبل ذلك وعرف حننها، فإن قيل : قوله : إنها وضيئة، وترتيبه على ذلك بالفاء، قوله : فطقق الفضل ينظر إليها، وقوله : وأعجبه حسنها، فيه الدلالة الظاهزة على أنه كان يرى وجهها، وينظر إليه لإعجابه بحسنه، فالجواب : أن تلك القرائن لا تستلزم استلزاما، لا

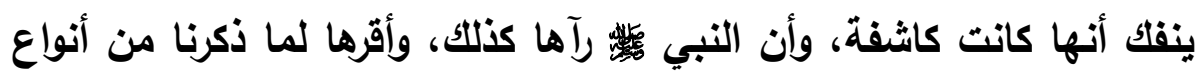
الاحتمال، مع أن جمال المرأة قد يعرف وينظر إليها لجمالها وهي مختمرة، وذلك لحسن قدها وقوامها، وقد تعرف وضاءتها وحسنها من روئية بنانها فقط، كما هو معلوم · ولذلك فسر ابن مسعود : (ولا يبدين زينتهن إلا ما ظهر منها)، بالملاءة فوق الثياب، كما تقدم • ومما يوضح أن الحسن يعرف من تحت الثياب، قول الثاعر : طافت أمامة بالركبان آونة يا حسنها من لن 
قوام ما ومنتقبا، فقد بالغ في حسن قوامها، مع أن العادة كونه مستورا

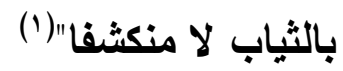

ومن ناحية أخرى فإنه يجوز للمحرمة أن تكثف عن وجهها لأجل الإحرام،

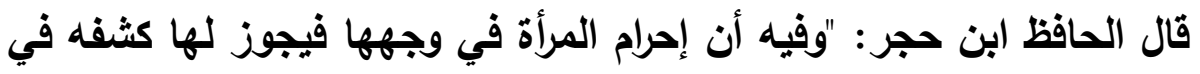
الإحرام"(ץ)، ولما قال ابن بطال : " وفيه دليل على أن ستر المرأة وجهها ليس فرضا، لإجماعهم على أن للمرأة أن تبدي وجهها في الصلاة، ولو آلو آهاه

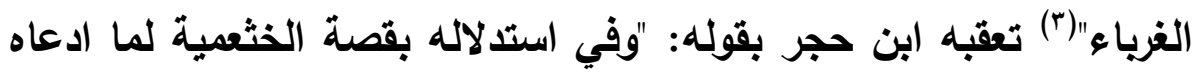

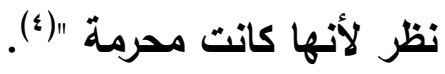
وقال الثنقيطي: "المرأة محرمة وإحرام المرأة في وجهها وكفيها، فعليها

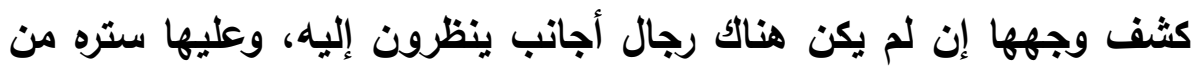

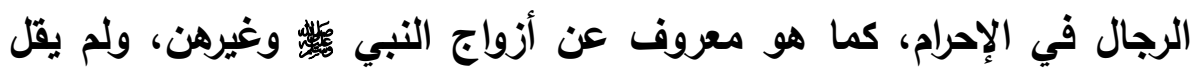

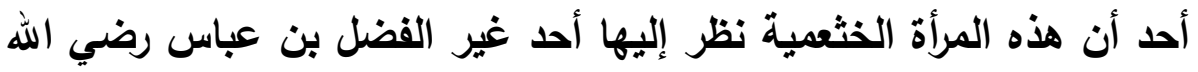

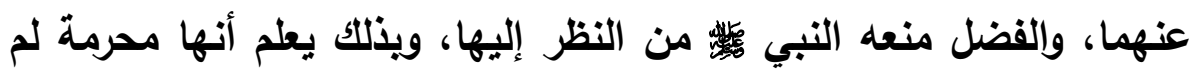
ينظر إليها أحد فكثفها عن وجهرا إذا لإحرامها لا لجواز السفور .

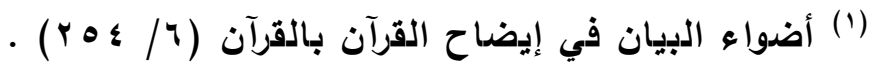

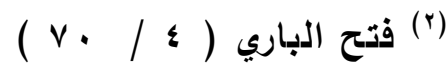

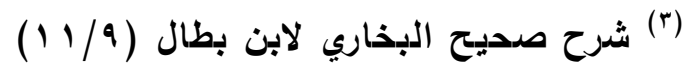

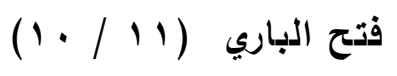


فإن قيل : كونها مع الحجاج مظنة أن ينظر الرجال وجهها إن كانت سافرة ؛ لأن الغالب أن المرأة السافرة وسط الحجيج، لا تخلو ممن ينظر إلى وجهها

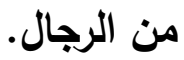

فالجواب : أن الغالب على أصحاب النبي إن الورع وعدم النظر إلى النساء،

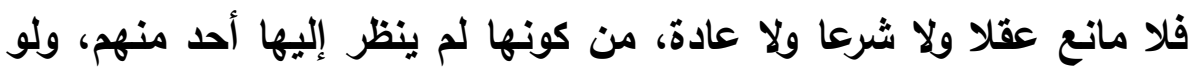

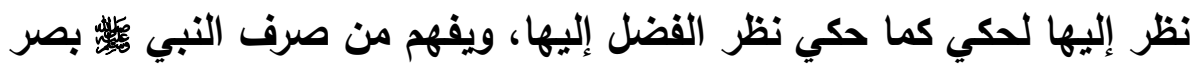
الفضل عنها، أنه لا سبيل إلى ترك الأجانب ينظرون إلى إلى الثابة، وهي سافئرة

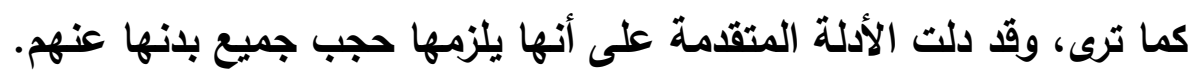
ويالجملة، فإن المنصف يعلم أنه يبعد كل البعد أن يأذن الثارع للنساء

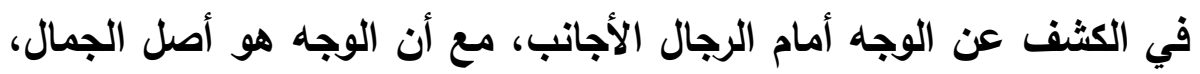

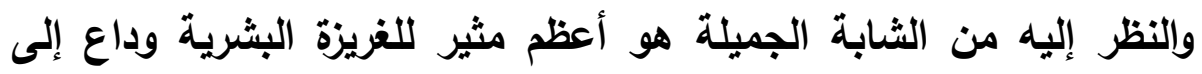

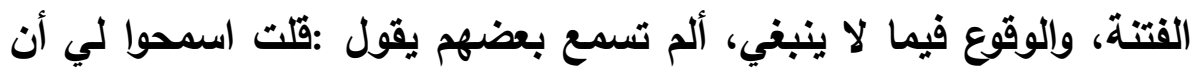

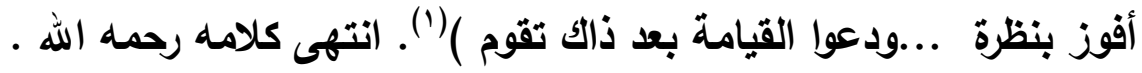
كما أنه يحتمل أن وجه المرأة انكشف بغير قصد منها، وأنها لم تتعد ذلك

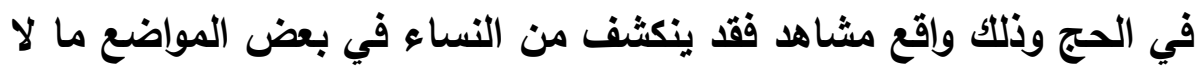
تريد كثفه، وخاصة في المواطن المكشوفة في غير البناء الذي هو مظنة 
هبوب الرياح، وهكذا كانت الحالة في الحج، وعلينا أن نستحضر أن اللباس

في الماضي مما قد يسهل انكثافه، وفي نحو ذلك قال النابغة الذبياني ('): سقط النصيف ولم ترد إسقاطه

كما أنه يحتمل أنها كانت في موضع متحيز أول الأمر وكانت تظن أن

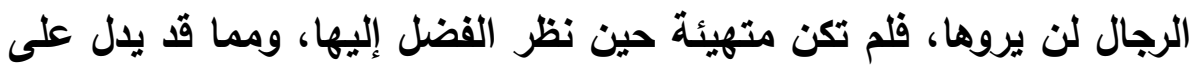

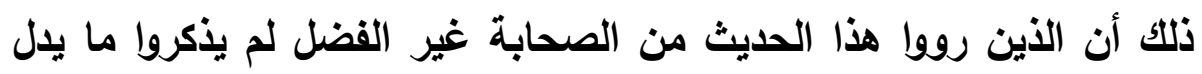
على أنها كانت كاشفة عن وجهها كما في حديث علي -رضي الله عنه-

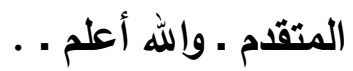

وقد أخرج البخاري هذا الحديث في كتاب الاستئذان، وكأنه يثير إلى أنها

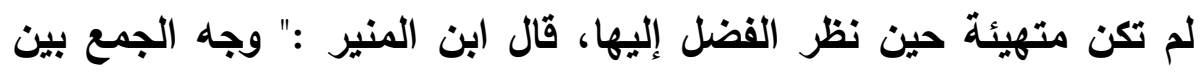

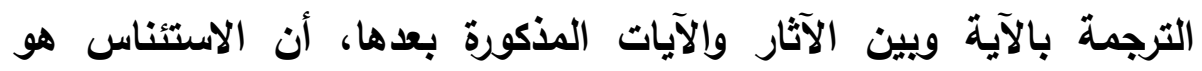
الاستئذان إنما جعل من أجل النظر خشية أن ترى العورة فجأة. فقرر بالآثار

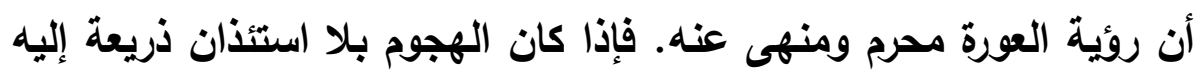
وجب تحريمه لأدائه إلى المحرم"(؟). ومن الاحتمالات الواردة أيضاً ما روي أن والدها أراد منها أن تكشف وجهها للنبي

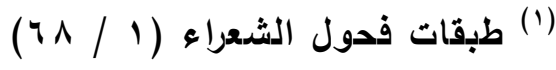

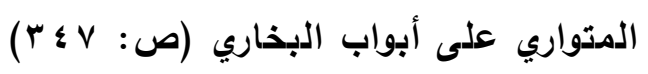


عن ابن عباس عن الفضل بن عباس قال :" كنت ردف رسول الله

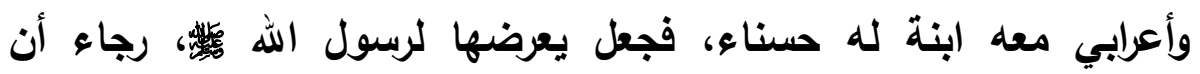

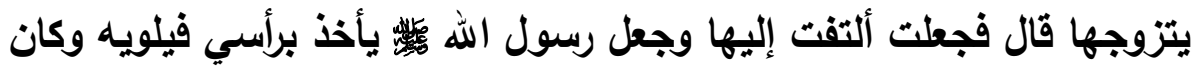
رسول الله ئس يلبي حتى رمى جمرة العقبة" ('). قال الحافظ (بن حجر : رواه أبو يعلى بإسناد قوي(†)، وقال الهيثمي : رجاله

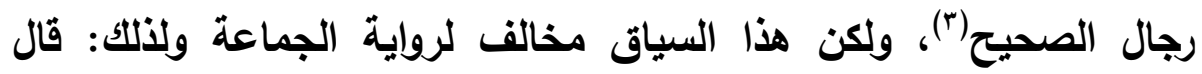
الألباني منكر بهذا السياق(؛)، أقول: هذا وإن كان ضعيفاً لكنه قد ورد وهو

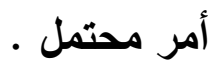

وعلى كل حال فإن في فعل النبي

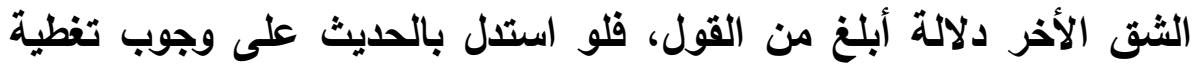

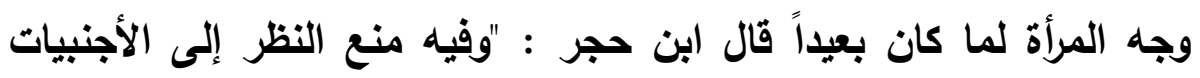

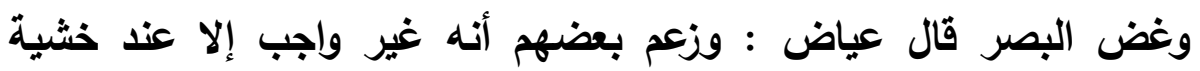

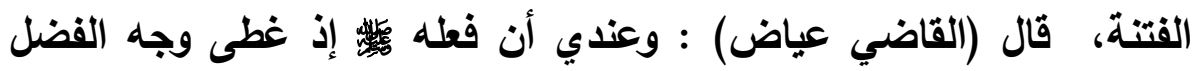

أبلغ من القول "(o.).

$$
\begin{aligned}
& \text { مسند أبي يعلى (T) }
\end{aligned}
$$

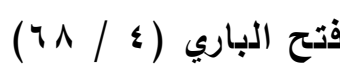

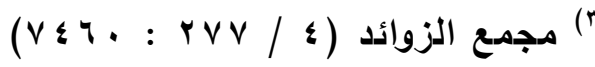

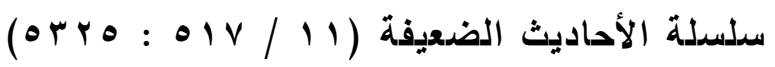

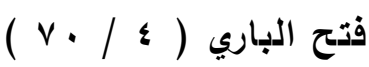


أقول وعليه فلا يصح أن يقال: إن النبي قال ابن قدامة -رحمه الله تعالى- في المغني : " وفي إباحة النظر إلى ألى

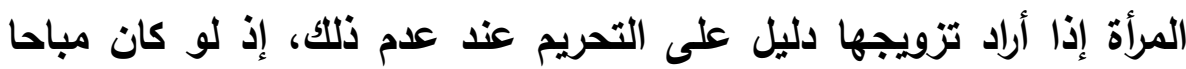
على الإطلاق، فما وجه التخصيص لهذه "((1). وقال ابن القيم رحمه الله تعالى في إعلام الموقعين: " وأما تحريم النظر

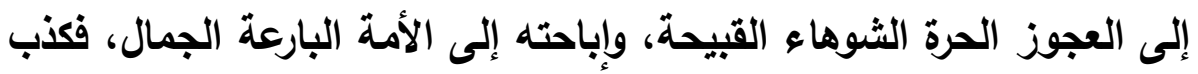

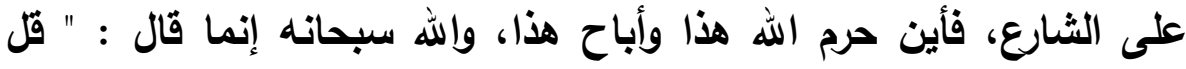

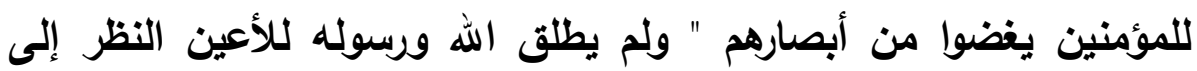

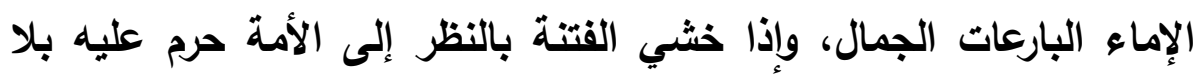

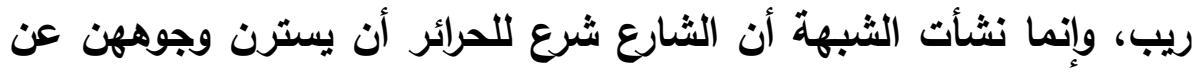

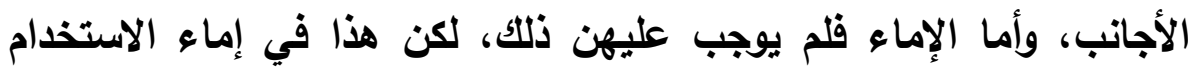

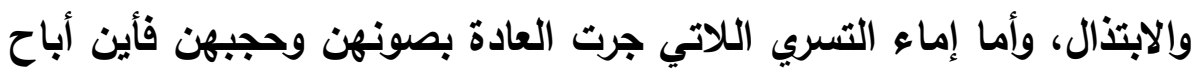
الله ورسوله لهن أن يكثفن وجوههن في الأسواق، والطرقات، ومجامع

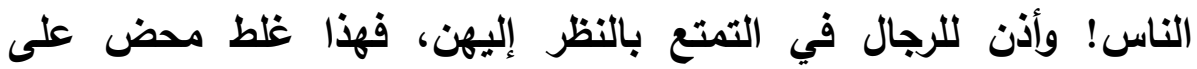

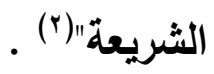

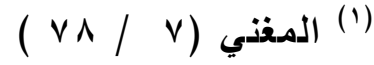

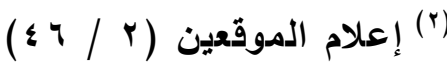




\section{|}

أحمد الله تعالى الأي تتم بنعته الصالحات، وإلى أهم النتائج والتوصيات التي

$$
\text { توصلاً : الليها من خلال البحث. }
$$

( ) أصح روايات حديث الخثعمية هي رواية ابن عباس عن أخيه الفضل

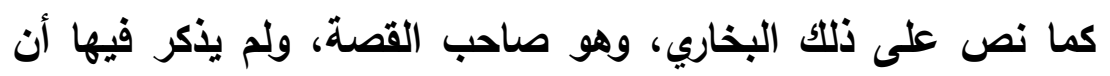
الخثعمية كاتت كاشفة عن وجهها، ولم يرد أنها كاتت حسناء، أو

وضيئة، أو قال الفضل إنه كان ينظر إلبها، أو أنه أعجبه حسنها .

r) أخرج البخاري الحديث من طرق أربعة من الرواة عن الزهري وهم مالك، وعبدالملك بن جريج، وعبد العزيز بن أبي سلمة، والأوزاعي،

$$
\text { ولم ترد فيها لفظة (وضيئة) ولا (حسناء). }
$$

r) حيث الخثعمية جاء في الصحيحين وغيرهما من طرق كثيرة عن الزهري من رواية كبار أصحابه عنه، ولم يرد فيها لفظة وضيئة أو حناء سوى رواية واحدة هي أبي اليمان عن شعيب بن أبي حزة. ع) لا يوجد في أي من الروايات في صحيح مسلم وصف المرأة بأنها كانت

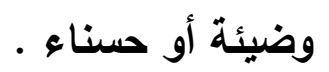

•) الروايات التي فيها أنها كانت (وضيئة)، يلاحظ عليها أمران؛ الأول: لم يروها كبار أصحاب الزهري عنه، والثاني: هذه اللفظة جاءت في نُسَخ 
حديثية فرواية أبي اليمان عن شعيب بن أبي حمزة عن الزهري إجازة

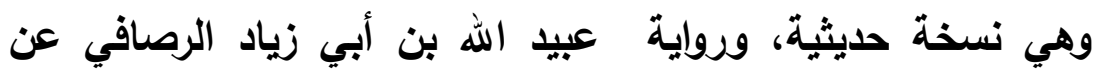

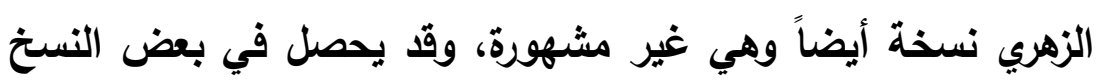

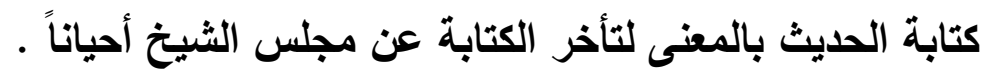
7) الأحاديث الصحيحة قد يقع فيها بعض الألفاظ التي لم يتفق عليها،

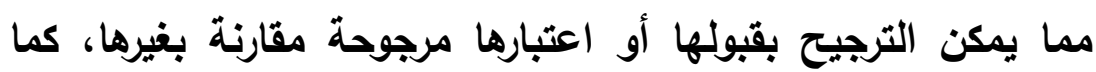

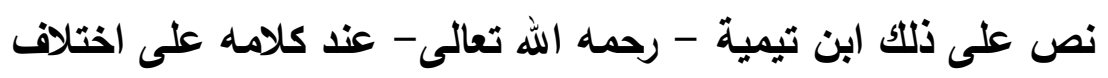

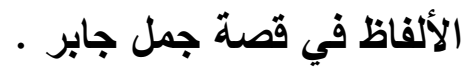

( الروايات التي ظاهرها الاختلاف أو التعارض في بعض الألفاظ لا يُسوِّغ

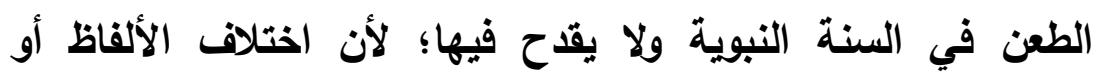

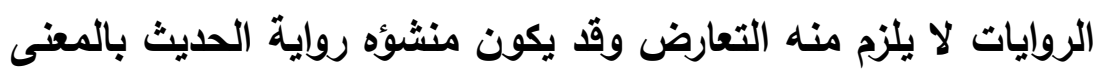
مع ثبوت أصل الحديث، والمقصود هو بيان الراجح فيما ظاهره التعارض وتمييز ما روي بالمعنى من غيره، ولا سيما عند الاستدلال واستتباط الأحكام الفقهية. ثانيــا : التوصيات:1) إفراد الأحاديث المشكلة بدراسات حديثية متخصصة من خلال النظر في الروايات والموازنة بينها. r) توجيه الباحثين وطلاب الدراسات العليا لتفعيل الجانب التطبيقي في دراسة الأحاديث النبوية. 


\section{المسادر والمراجع}

• الإرشاد في معرفة علماء الحديث لأبي يعلى الخليلي، خليل بن عبد الله

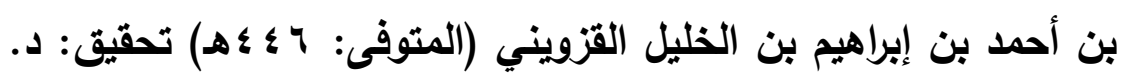

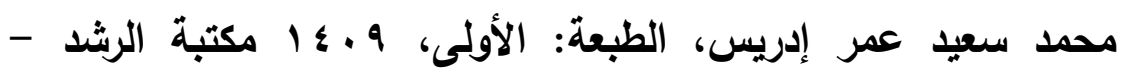

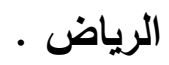

أضواء البيان في إيضاح القرآن بالقرآن، لمحمد الأمين بن محمد بن

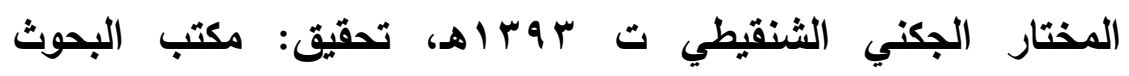

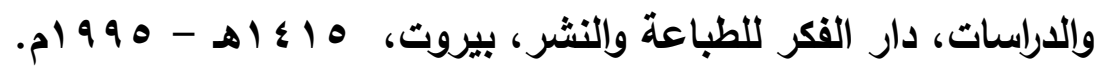

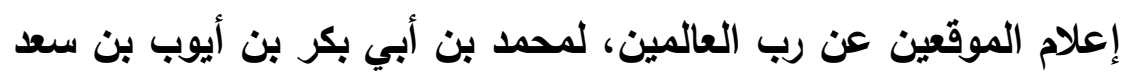

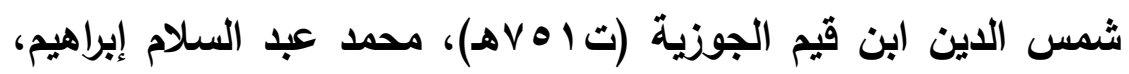

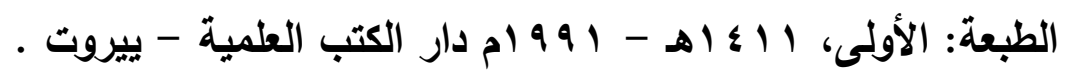

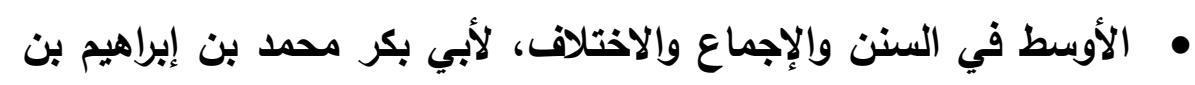

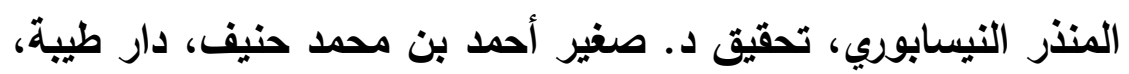

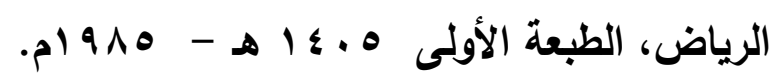

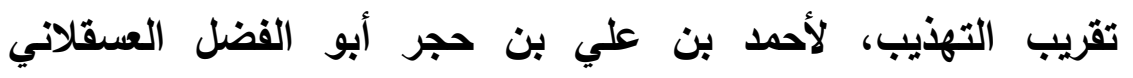

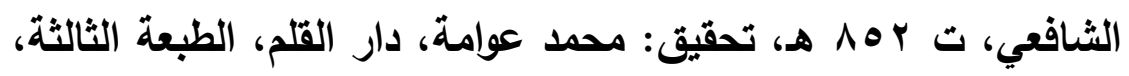

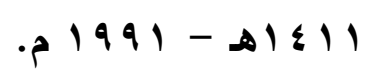

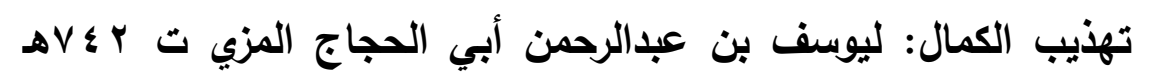

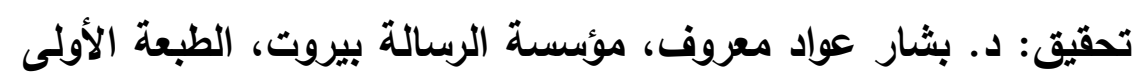

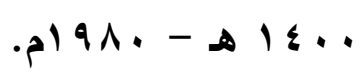


الجامع الصحيح المختصر من أمور رسول الله - صلى الله عليه وسلم - وسننه وأيامه،(صحيح البخاري) لمحمد بن إسماعيل أبي عبد الله

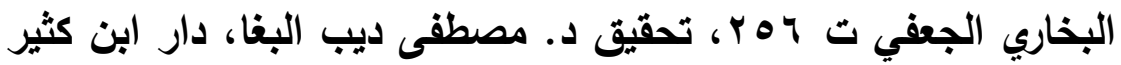

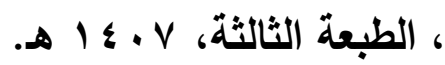
سلسلة الأحاديث الضعيفة والموضوعة وأثزها السيع على الأمة، لمحمد

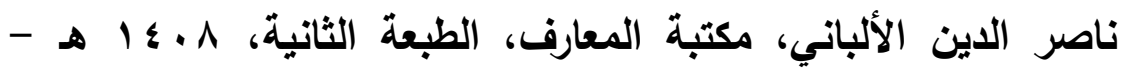
. $) 9 \wedge \wedge$ • سنن ابن ماجه: لمحمد بن يزيد أبي عبدالله القزويني ت ه Pـ، تحقيق: محمد فؤاد عبد الباقي، دار الفكر، بيروت . سنن الترمذي: لمحمد بن عيسى أبي عيسى الترمذي السلمي ت YV9، تحقيق: أحمد محمد شاكر وآخرون، مطبعة مصطفي البابي الحلبي،

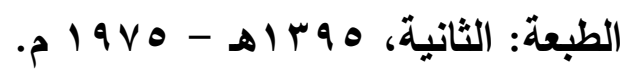
سنن الدارمي، لعبدالله بن عبدالرحمن أبو محمد الدارمي، تحقيق: فواز أحمد زمرلي ، خالد السبع العلمي، الطبعة الأولى، V • ـ اه دار الكتاب العربي - بيروت. - مئ.

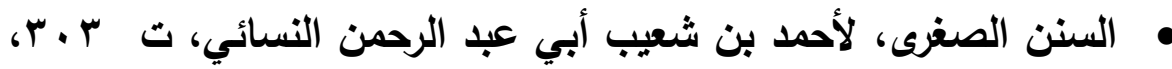

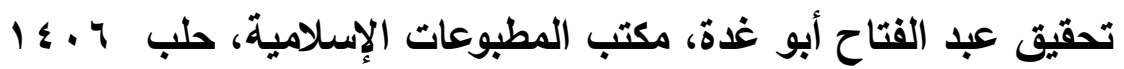
. 9 ه 9 ه • السنن الكبرى، لأحمد بن شعيب أبي عبد الرحمن النسائي ت ب. م هـ، تحقيق: د.عبد الغفار سليمان البنداري، وسيد كسروي حسن، دار الكتب 


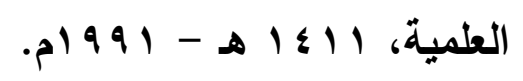

• شذرات الذهب في أخبار من ذهب، لابن العماد شهاب الدين أبي الفلاح

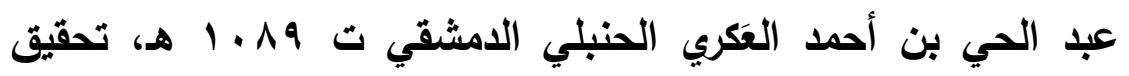

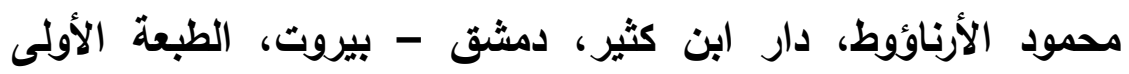

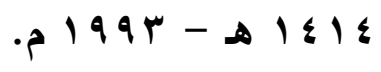

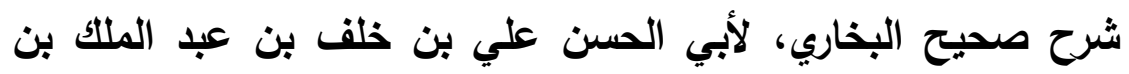

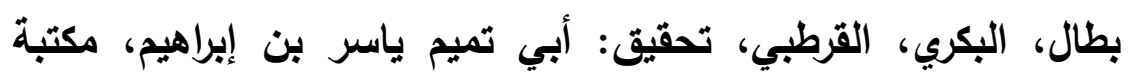

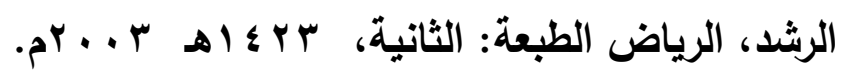

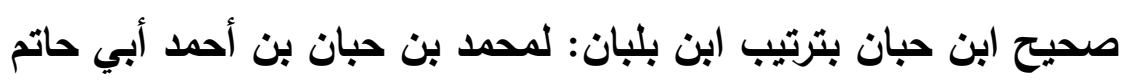

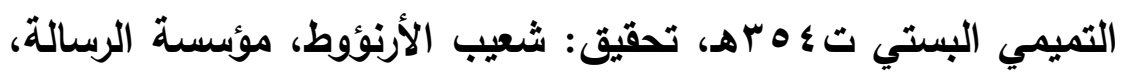

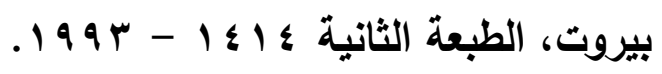
صحيح ابن خزيمة: لمحمد بن إسحاق بن خزيمة أبي بكر النيسابوري

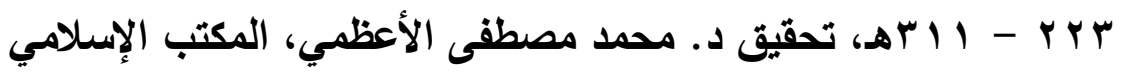

$$
\text { بيروت . }
$$

• صحيح مسلم، للإمام مسلم بن الحجاج أبو الحسين القثيري

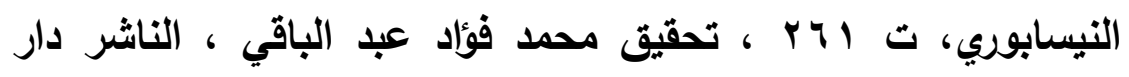

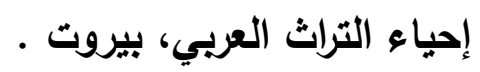
طبقات فحول الثعراء، لمحمد بن سلّام بن عبيد الله الجمحي بالولاء،

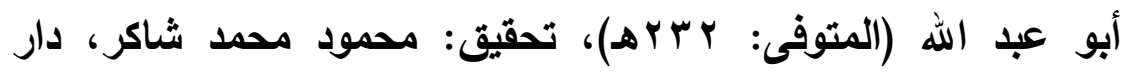

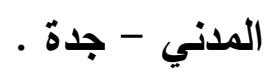


فتح الباري، لابن حجر، أحمد بن علي بن حجر أبو الفضل العسقلاني الشافعي، دار المعرفة، بيروت، IrVq هـ، ترقيم : محمد فؤاد عبد الباقي

الكفاية في علم الرواية، لأبي بكر أحمد بن علي بن ثابت بن أحمد بن مهدي الخطيب البغدادي (المتوفى: بآءه)، تحقيق: أبي عبدالله السورقي وإبراهيم حمدي المدني، المكتبة العلمية، المدينة المنورة . المتواري علي تراجم أبواب البخاري، لأحمد بن محمد بن منصور بن القاسم بن مختار القاضي، أبو العباس ناصر الدين ابن المنير الجذامي الجروي الإسكندراني (المتوفى: ب^آه)، تحقيق: صلاح الدين مقبول

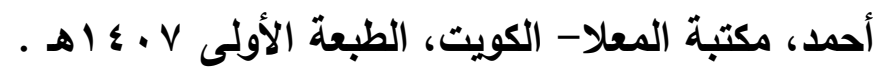
• مجمع الزوائد ومنبع القوائد، لأبي الحسن نور الدين علي بن أبي بكر

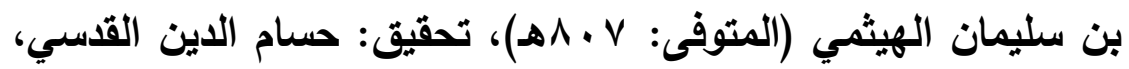

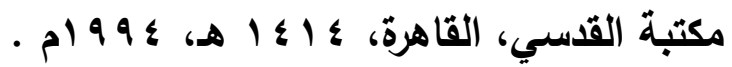
مجموع القتاوى، لتقي الدين أبو العباس أحمد بن عبد الحليم بن تيمية الحراني (المتوفى: هـ VA)، تحقيق: عبد الرحمن بن محمد بن قاسم، نشر: مجمع الملك فهر لطباعة المصحف الثريف، المدينة النبوية،

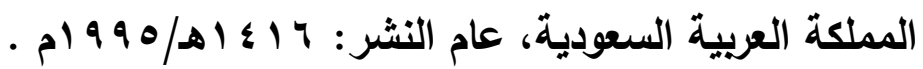
المحلى، لعلي بن أحمد بن سعيد بن حزم الظاهري أبي محمد، ت هـ تحقيق: محمد منير الامشقي، إدارة الطباعة المنيرية، طبع للمرة

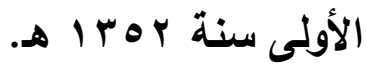


مسند أبي يعلى: لأحمد بن علي بن المثلى أبي يعلى الموصلي التميمي

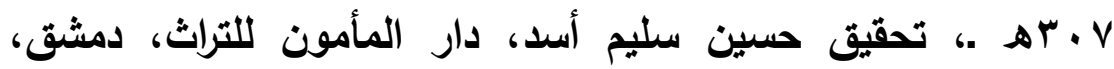

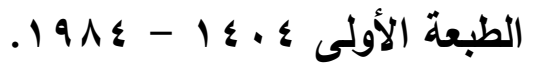
مسند الإمام أحمد بن حنبل: لأحمد بن حنبل أبي عبدالله الثيباني

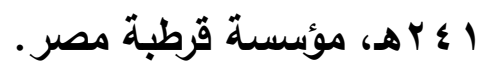
مشارق الأنوار على صحاح الآثار، لأبي الفضل عياض بن موسى مون اليحصبي ت \& \&ه هـ، طبع المكتبة العتيقة تونس، ودار التراث القاهرة.

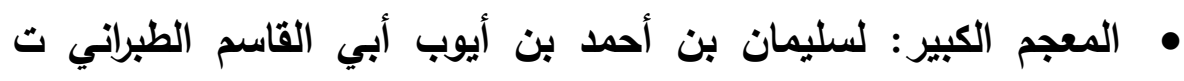
• . هـ، تحقيق: حمدي بن عبدالمجيد السلفي، مكتبة العلوم والحكم،

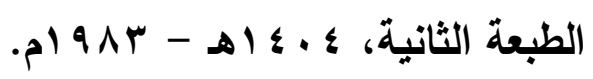
• المغني في فقه الإمام أحمد بن حنبل الشيباني، لعبدالله بن أحمد بن قدامة المقدسي أبي محمد (ت · r Tهـ ) دار الفكر، بيروت، الطبعة

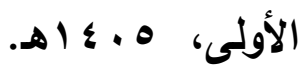

وفيات الأعيان وأنباء أبناء الزمان، لأبي العباس شمس الاين أحمد بن محمد بن أبي بكر بن خلكان، ت ا ^\ه، تحقيق: إحسان عباس، دار

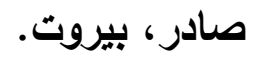

